This is a self-archived version of an original article. This version may differ from the original in pagination and typographic details.

Author(s): Böckerman, P.; Bryson, A.; Kauhanen, A.; Kangasniemi, M.

Title: Does job design make workers happy?

Year: 2020

Version: Accepted version (Final draft)

Copyright: (C) 2019 Scottish Economic Society

Rights: In Copyright

Rights url: http://rightsstatements.org/page/InC/1.0/?language=en

Please cite the original version:

Böckerman, P., Bryson, A., Kauhanen, A., \& Kangasniemi, M. (2020). Does job design make workers happy?. Scottish Journal of Political Economy, 67(1), 31-52.

https://doi.org/10.1111/sjpe.12211 


\title{
Does Job Support Make Workers Happy? ${ }^{1}$
}

\author{
Petri Böckerman*, Alex Bryson**, Antti Kauhanen***, Mari \\ Kangasniemi**** \\ * Corresponding author. University of Jyväskylä, Labour Institute for Economic Research \\ (Helsinki) and IZA (Bonn). Address: Labour Institute for Economic Research, \\ Pitkänsillanranta 3A, 00530 Helsinki. Phone: +358-9-25357330. E-mail: \\ petri.bockerman@labour.fi \\ ** UCL (London), NIESR (London) and IZA (Bonn) \\ *** The Research Institute of the Finnish Economy (Helsinki) \\ **** Food and Agriculture Organization of the United Nations (Rome). This work was \\ carried out while Mari Kangasniemi was working in the Labour Institute for Economic \\ Research
}

\begin{abstract}
Using linked employer-employee data for Finland we examine associations between job design and ten measures of worker wellbeing. In accordance with Karasek's (1979) model we find positive correlations between many aspects of worker wellbeing and job control. However, contrary to the model, job demands have no adverse effects on worker wellbeing. We find a strong positive correlation between job support and all aspects of worker wellbeing that is independent of job controls and job demands, a finding that has not been emphasized in the literature. The effects are most pronounced in relation to supervisor support. We also find evidence of unemployment scarring effects: substantial experience of unemployment has long-term consequences for the wellbeing workers experience in their current jobs, even controlling for the quality of those jobs.
\end{abstract}

Key Words: worker wellbeing; job control; job demands; job support; job design; supervisors; job satisfaction; stress; HRM; unemployment; scarring effects.

JEL Classification: J28; J8; L23; M54.

\footnotetext{
${ }^{1}$ This paper is a part of the project (4112/31/2014) financed by TEKES (National Technology Agency of Finland).
} 


\section{INTRODUCTION}

In the standard labour supply model there is a marginal disutility to additional work because performing it eats into leisure time. Consequently, people are paid to work and will respond to financial incentives with greater effort at the extensive and intensive margins. Recent research on momentary wellbeing is consistent with this proposition: working is second only to being sick in bed when individuals are randomly dinged on their smart-phone and asked how happy they are during an activity (Bryson and MacKerron, 2017). At the same time, paid work contributes to higher reported life satisfaction, even after controlling for income, and individuals report being more fulfilled when their lives include paid employment (Blanchflower and Oswald, 2011). Their life satisfaction is particularly adversely affected by bouts of unemployment. Indeed, unemployment is one of the few episodes in life that people struggle to recover from in happiness terms (Clark et al., 2008).

These findings on the adverse and positive associations between wellbeing and paid employment are not necessarily contradictory. Rather they reflect the influence of paid work on different aspects of wellbeing: when individuals reflect back on their lives paid work contributes to satisfaction with that life but, at the margin, individuals would often rather be doing something else.

When examining the relationship between wellbeing and paid work one should be mindful not only of the different dimensions of wellbeing, but also that not all jobs are the same. This literature began as far back as Adam Smith's discussion of compensating wage differentials in The Wealth of Nations (1776) in which he argued that workers were more likely to undertake jobs with poor working conditions where they commanded a higher wage to compensate them for those conditions. More recently a literature in psychology has revisited 
the issue of non-pecuniary job attributes and their influence on worker wellbeing. The seminal work in this field has been undertaken by Karasek (1979) and Karasek and Theorell (1990). The original model focuses on two key aspects of job design: the demands the job makes on the individual and the degree of control the employee has over aspects of their job (what Karasek termed "job decision latitude"). Under the model job demands create job stress, thus having a negative impact on worker wellbeing, while job control has a positive direct influence on wellbeing, as well as being able to mitigate the adverse effects of job demands. It is the combination of low job control and high job demands that is associated with mental strain and job dissatisfaction. As we shall see in Section Two, many empirical studies confirm these propositions. Subsequent empirical studies have incorporated forms of job support (supervisory, co-worker and non-work) and find these can mitigate the effects of job demands on job stress.

We contribute to this literature in two ways. First, we seek to identify the association between job design and worker wellbeing having taking account of worker selection into jobs that differ along the dimensions of job control, job demands and job support. We do so by conditioning on workers' labour market histories prior to entering their current job. Earlier research has shown that the wage returns to undertaking particular jobs are substantially overstated if one does not account for worker sorting along these dimensions (Böckerman et al. 2013). Therefore, we consider the sensitivity of the link between job attributes and wellbeing to the inclusion of work histories. Second, we use rich nationally representative linked employer-employee data for Finland to see whether findings from the empirical literature hold in the Finnish setting.

The Finnish setting has broader interest for several reasons. First, Finland is known for its high take-up of high involvement management practices which are characterized by high 
levels of job control and job demands (Böckerman et al., 2012). Second, in contrast to much of the literature which is conducted in Anglo-American countries with low unionization rates, Finland has high unionization. Prior research suggests that the outcomes for workers can be different in countries with high unionization (Godard, 2004). This may be the case with regard to job design, for instance, where union membership rates of around 70 percent in Finland imply a substantial worker say in how jobs are designed. Third, despite a potential role for worker voice in the implementation of job design, Finland has the highest sickness absence rate in the European Union (Gimeno et al., 2004), raising questions about the link between job design and worker wellbeing.

We find that in accordance with the theory of Karasek (1979) and Karasek and Theorell (1990) job control and supervisory support are positively correlated with employee wellbeing and negatively correlated with job-related stress. As predicted, job demands are positively correlated with job-related stress. However, there is no association between job demands and employee wellbeing and, contrary to expectations, neither job control nor supervisory support alleviate the negative relationship between job demands and job-related stress.

\section{LITERATURE}

Karasek's (1979) model of worker wellbeing as a function of job design has been labeled "perhaps the most popular theory of the predictors of job wellbeing" (Wood, 2008, 156). It maintains that, when entered separately into a worker wellbeing equation in an additive fashion job demands adversely affect employee wellbeing, whereas job control is positively associated with wellbeing. Furthermore, in a multiplicative model in which job control and job demand are interacted with one another job control will mitigate the adverse effects of 
job demands. A large empirical literature has emerged testing these propositions. Reviews of the early empirical literature indicated substantial support for the additive model and some, though less compelling evidence, for the multiplicative model (de Lange et al., 2003; van der Doef and Maes, 1999).

More recently regression analyses of British linked employer-employee data indicated that "the characteristics of the job are considerably more important in influencing wellbeing than employee or workplace characteristics" (van Wanrooy et al., 2013, 130) and provided strong support for Karasek's additive model using three different measures of worker wellbeing, namely job-related contentment, job-related enthusiasm and overall job satisfaction (van Wanrooy et al., 2013, p. 129-134). These findings were broadly replicated in a subsequent comparative analysis of job satisfaction for Britain and France using linked employeremployee data (Bryson et al., 2016, p. 204-205).

Payne (1979) added support to the demand and control model by arguing that various types of support at the workplace, particularly social support from supervisors and colleagues, could assist employees in dealing with high demands, thus lowering work strain and stress. Karasek and Theorell (1990, 68-76) subsequently incorporated support into Karasek's original model. Wood $(2008,156)$ identifies three channels by which social support may buffer the adverse effects of job demands: role clarity, helping people "manage" their feelings better and, following Warr (2011), motivational support intended to reassure workers that their extra efforts will eventually reap rewards.

Early empirical studies found some evidence to suggest that low social support among those facing high job demands and low job control accentuated job strain (Landsberger et al., 1992; Payne and Fletcher, 1983) and cardiac risk (Johnson and Hall, 1988). More recent evidence only finds partial support for the buffering role of social support. Sargent and Terry's (2000) 
study of university clerical workers found clear evidence that, when combined with high job control, high levels of supervisory support mitigated the adverse effects of job demands on both job satisfaction and feelings of depersonalization, while co-worker support and nonwork support did not. Using nationally representative linked employer-employee data for Britain Wood (2008) finds that supportive management does not buffer the effects of job demands in raising job-related anxiety.

Analysts' desire to test the Karasek model has meant they have focused on the main effects of job demands, job controls and the interaction between the two, as well as the buffering role of social support. In doing so they have downplayed the independent effects of social support in isolation, and the other multiplicative effects when combining support, demands and control. This is somewhat surprising given the importance of social interactions to human beings in a range of contexts. Kahneman et al.'s (2004) Day Reconstruction Method study indicated that individuals prefer being with almost anybody compared to being on their own. Bryson and MacKerron (2017) find "Talking, Chatting and Socialising" ranks seventh out of forty activities in terms of its association with momentary happiness, and that it is only when one is doing this that the underlying negative effect of working on momentary happiness is wiped out (Bryson and MacKerron, 2017, p. 16). It is possible that part of this "social" effect at work is because being with others is a distraction from work activity, or is simply pleasurable in its own right.

However, a number of the studies discussed above also find supportive management has a direct effect on worker wellbeing. For instance, Wood (2008) finds that supportive management, consultative management and informative management are all positively and significantly associated with lower job-related anxiety and higher job satisfaction. Similarly, van Wanrooy et al. (2013, p. 132-134) find that the main effect of their supportive 
management scale is positive and statistically significant in models estimating job-related contentment, job-related enthusiasm and overall job satisfaction. Bryson et al. (2016, p. 204205) also find this is the case for job satisfaction in their comparative analysis of British and French employees in the private sector.

One complication is that there is an exception to Kahneman et al.'s (2004) general finding that people are happier when they are with others. The exception is when they are with their boss. It seems likely that the effects of supervisory "support" depend on the quality of the relationship between a worker and his or her supervisor. Recent evidence from Denmark finds that having an unsupportive boss leads to a large increase in the probability of voluntary quits (Cottini et al., 2011). This might also explain why Sargent and Terry (2000) observe that supervisory support has no direct independent association with job satisfaction whereas the main effect of co-worker support on job satisfaction is positive and statistically significant. Using both British and U.S. data Artz et al. (2016) focus on boss competence and show that it is a very important determinant of employee job satisfaction.

There are two potentially important drawbacks to the literature examining links between worker wellbeing and job design. The first is that the partial correlations presented in regression analyses pay little attention to non-random sorting into jobs by workers. This is a potentially important oversight since there is a substantial literature about workers and firms seeking good worker-job matches (Jovanovich, 1979). Where workers are heterogeneous in their tastes for hard work (job demands), and their desire for autonomy (job control), or where heterogeneous risk preferences mean employees place various amounts of weight on the support they will receive from their supervisor to perform a task, workers will sort into different types of job according to the utility they think they will derive from the job. ${ }^{2}$ At the

\footnotetext{
2 This is a finding that crops up in a number of settings. For example, Plug et al. (2014) show that gays and lesbians behave in response to their perceptions regarding the incidence of prejudice by sorting themselves into
} 
same time, employers may signal their desire for certain types of worker conditional on the jobs they have available, as in the case of Lazear's (2000) model in which firms seek more productive workers through the use of incentive schemes. It seems very likely that worker sorting across firms arising from worker and employer choices, will result in non-random exposure to job demands, job controls and job support, imparting a bias to estimates of the links between job design and worker wellbeing if one cannot account for that sorting. A priori it is unclear which way any bias may go. It depends, in part, on how efficient the labour market is in allocating workers to the jobs they would ideally like to perform. If certain types of jobs are rationed (in the sense that demand for them exceeds their supply), effects of job demands, for example, may prove more negative for worker wellbeing than in a scenario in which all workers sort into the types of jobs that best suit their preferences.

We address sorting by conditioning on workers' labour market and earnings histories in the previous ten years, as detailed in Section Three. There are two reasons to condition on work and earnings histories. The first is that employers seek out high ability workers to work in demanding jobs - that is, those with high demands and high job autonomy. This explains why the wage premium attached to "high involvement" jobs falls conditioning on employees' work histories (Böckerman et al., 2013). If there is a correlation between ability and wellbeing that is not accounted for in our model, this may bias our estimates of the links between job design and worker wellbeing. ${ }^{3}$ Conditioning on work histories therefore helps to identify potential misallocation of workers to jobs, giving us greater confidence that the model accurately identifies the link between worker wellbeing and job design for "like"

\footnotetext{
occupations with more tolerant employers and co-workers - the sort of behaviour one might anticipate when workers are concerned about the amount of job support they might receive from supervisors and colleagues.

${ }^{3}$ Such a correlation is plausible. There is a literature indicating that the job satisfaction of workers is negatively correlated with observable indicators of ability such as education and earnings (Clark and Oswald, 1996). If observable and unobservable indicators of ability are positively correlated this would suggest the incorporation of work histories may mitigate the bias.
} 
employees. The second reason is that, as the programme evaluation literature makes clear, matching on work histories helps soak up otherwise omitted variables that can bias estimates of the effect of treatments on labour market outcomes (Barnow and Smith, 2015). Thus, notwithstanding concerns about non-random worker-job sorting, it is likely that conditioning on work histories will partial out otherwise unobserved worker heterogeneity which could potentially bias our estimates.

The association between prior unemployment and subsequent worker wellbeing is of particular interest. Previous studies confirm that past unemployment has a scarring effect on individuals' psychological wellbeing, even when conditioning on current employment status (Clark et al., 2001). This could reflect the inhibiting effect of a poor work history in obtaining a higher quality of job in the future. However, no studies condition on current job quality when examining the links between past unemployment and current worker wellbeing.

A second potential limitation to the existing literature is that few studies examine the links between job design and multiple aspects of employee wellbeing. Consequently, it is difficult to know whether the different associations between job design and worker wellbeing reflect cross-study differences in methodology, the population of interest, sampling design and data items, or whether the differences reflect genuinely different associations between job design and alternative measures of worker wellbeing. This would not be a concern if wellbeing measures were really slightly different takes on the same underlying construct but this is not the case (Bryson et al., 2017). As we show in the next section, we run analyses for two key worker wellbeing measures that have a low inter-item correlation. 


\section{DATA AND ESTIMATION}

The analyses are based on the Finnish part of the European Meadow project Measuring the Dynamics of Organisations and Work conducted by Statistics Finland (Meadow Consortium, 2010; Alasoini et al., 2014). The aim was to gather comprehensive information on the changes in work organisation and perceived working conditions. The survey covers both Finnish private and public sector organisations excluding employers that had fewer than 10 employees in 2010 .

Although employer representatives and employees were interviewed our analysis is based on the employees' survey which contains information on multiple facets of employee wellbeing. ${ }^{4}$ Respondents are confined to those who have worked at least one and half year in their current employer before interview. The response rate to the employees' survey was approximately 50 per cent. ${ }^{5}$

The dependent variables in the regression models describe two crucial aspects of employee wellbeing. ${ }^{6}$ The first one is a wellbeing measure that is constructed using three items of the survey. The scale has Cronbach's alpha of 0.85 . We standardize the scale to have zero mean and standard deviation of 1 . The first item asks: "In your current job, do you feel enthusiasm

\footnotetext{
${ }^{4}$ Sampling was such that, in the vast majority of cases, there is only one respondent per employer.

${ }^{5}$ When using the survey weights calibrated by Statistics Finland, the Meadow survey is representative of Finnish workplaces employing more than 10 workers. It is not necessarily representative of employees because the sampled employees had to have a tenure of at least 18 months (Minkkinen et al., 2013). We use the survey weights in our analysis.

${ }^{6}$ The Meadow survey contains a number of specific questions about employee wellbeing in which respondents were asked to assess perceived working conditions at their workplace. These include the experience of achievement, joy of working, trust and co-operation, expertise, management and supervisory work, taking care of employees' interests, adoption of employees' ideas and initiatives, boldness to propose fresh ideas that improve work, and fostering fairness. We report the estimation results for these additional items in the working paper version.
} 
and joy from working?" with responses coded "a lot", "a fair amount", "some", "little” and "not at all". The second item captures feeling and thoughts at work using three dimensions: "I feel strong and energetic in my job", "I feel enthusiasm about my job" and "I feel satisfaction when I'm immersed in my work". The responses to these questions are given with the alternatives: "Every day", "A few times a week", "Once a week", "A few times a month", "Once a month", "A few times a year" and "Never". The third item is: "All in all, how satisfied are you with this job?", with responses measured on a four-point Likert scale from "Very dissatisfied" (coded 1) to "Very satisfied" (coded 4).

The second dependent variable captures perceived work stress. According to the survey questions stress means a condition where one feels oneself tense, uneasy, anxious or distressed or he or she has difficulties sleeping as worrying interferes with sleep. The responses were given on a five-point Likert scale from "Not at all" (coded 1) to "Very much" coded 5).

To evaluate the empirical validity of the Karasek model we consider the association between global measures of wellbeing and job control, job demands and organisational support. Job control is measured in terms of employees' influence over four aspects of their job, namely the tasks they perform, the pace of work, the order in which they carry out tasks, and the distribution of tasks among workers. The answers to these questions are available on a fourpoint Likert scale ("not at all" (coded 4), "some" (coded 3), "a fair amount" (coded 2) and "a lot" (coded 1)). We reversed the original values so that higher values mean better control and formed a standardized scale. ${ }^{7}$ The scale has a Cronbach's alpha of 0.68 .

Job demands are evaluated based on five separate questions. The first one asks "How often does your job involve working to tight deadlines or at very high speed?", measured as a

\footnotetext{
${ }^{7}$ See the Appendix for further details on how the standardised scales are created.
} 
fraction of total working time with four pre-coded responses: less than $25 \%, 25-50 \%, 51-$ $74 \%$ and $75 \%$ or more. The second measure asks "How often do you carry out tasks related to your main job at home?", with alternatives "never", "occasionally", "frequently". 8 The third measure asks "How often you carry out tasks related to your main job outside your actual hours of work?", with alternative responses "every day", "at least once a week", "at least once a month" and "less often than once a month/never. The fourth measure asks "How often are you contacted by phone or in person on work-related matters outside your usual working hours" with alternatives "every day", "at least once a week", "at least once a month" and "less often than once a month/never". The fifth measure is based on responses to the question "Over the past 12 months how many hours per month have you worked overtime or done extra work during an average month?". Responses are given in terms of numbers of hours. We have capped the number of overtime hours at 40 to reduce the impact of some very large values that are not consistent with the Finnish labour law. This affects 31 observations. Using these five items on job demands we create a standardized scale. The items are quite highly correlated. The scale has a Cronbach's alpha of 0.73 .

Organisational support is identified with a single question which asks: "In case of work overload or a difficult situation, do you receive assistance from ... Your supervisor or manager; Your co-workers; Your clients or cooperation partners?" Pre-coded responses are "always", "sometimes" and "never". We form three different measures for job support. Supervisor support obtains the value of 1 if a worker obtains support always from his/her supervisor or manager (otherwise 0). The variables for co-worker support and client or cooperation partner support are formed similarly.

\footnotetext{
${ }^{8}$ This question has also a category "I only work at home", but we drop these observations.
} 
Initially we estimate models confined to the main effects for job control, job demands and organisational support. These are followed by models including the full set of interactions for job control, job demands and organisational support. We run Ordinary Least Squares (OLS) regression models for our global measures of employee wellbeing, because OLS makes it easy to interpret the estimated coefficients. We control for the standard determinants of employee wellbeing based on the empirical literature. We control for log annual income from administrative data, age, gender, educational level (6 groups), 2-digit occupation (39 groups), tenure (i.e. work experience at the current employer) and 1-digit industry (15 groups). ${ }^{9}$ To extrapolate the results to the population, we use survey weights that are calibrated and provided by Statistics Finland in all estimations. To account for the fact that there are a small number of workers who are employed in the same firms, the standard errors are clustered at the firm level.

The Meadow survey data are cross-sectional and include only very limited self-reported information on labour market experience. To account for employee sorting into different types of jobs we link the Meadow data to longitudinal register data from Statistics Finland. ${ }^{10}$ The register data are the Finnish Longitudinal Employer-Employee Data (FLEED). The FLEED is constructed from a number of registers on individuals and firms that are maintained by Statistics Finland. We link the Meadow data and the FLEED by using unique personal identifiers (i.e. identification codes for individuals).

Using FLEED we have followed the employees that were included in the Meadow survey in 2012 over the period 2001-2011. The work history variables are the average earnings, the

\footnotetext{
${ }^{9}$ Collective labour agreements are almost always binding also for non-union members in Finland. Thus, the coverage rate of collective labour agreements is about $90 \%$. This implies that individual union membership is not relevant in Finland. For this reason, most Finnish surveys on work life such as the one that we use in the paper do not record the union status of individual workers.

${ }^{10}$ For an earlier application of the same idea in the Finnish context, see Böckerman et al. (2013).
} 
number of unemployment months and earnings growth during the past ten years. The past earnings data are introduced as the log of annual earnings. Earnings include the base wage, overtime pay, bonuses, and wage supplements.

\section{RESULTS}

Table 1 reports means and standard deviations for key data items in the analysis for the estimation sample. ${ }^{11}$ Stress is coded on a scale from 1 to 5 and employee wellbeing is a summary scale. Job demands, job control and job support are composed of the items discussed in Section Three. For the purpose of analysis they are converted to standardized scores with a mean of zero and standard deviation of 1 . The table also shows means and standard deviations for control variables taken from the survey and the three work history variables derived from the administrative data.

\section{[INSERT TABLE 1]}

Table 2 shows the partial correlations between job control, job demands and supervisor support with wellbeing in columns (1) to (5) and with job-related stress in columns (6) to (10). Control, demands and support are entered alone, then together, with the final model specification also conditioning on work histories. The models account for up to 29 percent of the variance in employee wellbeing and 24 percent of the variance in job-related stress.

\section{[INSERT TABLE 2]}

\footnotetext{
${ }^{11}$ Appendix Table A3 shows the incidence of jobs with all combinations of job support, control and demands in the data.
} 
Throughout both job control and supervisor support are positively associated with wellbeing and negatively associated with stress. The size of the coefficients is fairly large. For example, a one standard deviation increase in job control increases well-being by about 0.3 standard deviations and reduces stress by about 0.13 standard deviations. Job demands are positively and significantly associated with stress, as predicted under Karasek's (1979) model. A one standard deviation increase in job demands increases stress by 0.4 standard deviations. Job demands are not significantly associated with wellbeing, although they are positively signed, perhaps reflecting the fact that some workers enjoy the challenges posed by their jobs, even when they create stress and anxiety. ${ }^{12}$ The size and significance of coefficients on control, demands and support do not vary greatly with model specification, with the exception of supervisor support where the coefficient falls but remains highly statistically significant with the introduction of job demands and controls. ${ }^{13}$

We hypothesized that the association between control, demand and support might be partly attributable to worker sorting across jobs according to their preferences and personality traits. If this is the case it is not picked up with the introduction of work history controls in models (5) and (10). These work history measures do not add to the variance accounted for in the model, they are not jointly statistically significant, and they do not have any material effect on correlations between control, demand and support and employee wellbeing and stress.

Table 3 incorporates interactions between job control, job demands and supervisor support to test the propositions that both job control and supervisor support should ameliorate the negative effects of job demands on employees' wellbeing and their positive effects on stress. Three model specifications are presented: main effects and interactions with industry and

\footnotetext{
${ }^{12}$ We have confirmed that there is no evidence for non-linearity of the effects for job demand.

${ }^{13}$ Results are similar when we exclude log annual earnings which might compensate employees for being in jobs they do not enjoy, or which cause them anxiety. This lends support to the non-existence of compensating wage differentials. These results are available on request.
} 
occupation dummies; a second model also incorporating additional demographic and job characteristics; and a final model adding work histories. None of the interaction effects are statistically significant, either jointly or independently, so there is no support for the mediating effects of job control and supervisor support. Encouragingly, the main effects for supervisor support and job demands reported in Table 2 are robust to the inclusion of the interaction effects. However, while the positive association between job control and employee wellbeing is robust, the negative coefficient for job controls in the stress equations falls in size a little and is only on the margins of statistical significance. In summary, there is no support for the mediation hypothesis.

\section{[INSERT TABLE 3]}

Employees may receive job support from people other than their supervisors. To see how that support is associated with worker wellbeing and stress we replace supervisory support with support from colleagues in Table 4 and clients/business partners in Table 5. Table 4 indicates that colleague support is significantly associated with lower job-related stress, but is not associated with employee wellbeing. Echoing the earlier results, its interactions with job control and job demands are not significant. Client support is not statistically significant for employee wellbeing or stress, either in isolation or in combination with job demands and controls. It appears that who is giving the support therefore matters, with supervisors playing a central role in employees' wellbeing and stress, while colleagues can help alleviate stress. ${ }^{14}$

\section{[INSERT TABLES 4 AND 5]}

\footnotetext{
${ }^{14}$ If all three support variables are incorporated to the model at the same time the ranking remains intact.
} 


\section{CONCLUSIONS}

It is well-established in the psychology, labour economics and HRM literatures that job design is strongly correlated with worker wellbeing. The literature has tended to focus on those aspects of job design featuring in Karasek's (1979) and Karasek and Theorell's (1990) models, notably job control, job demands and organizational support. The empirical literature tends to find strong support for an additive model in which job controls tend to be positively correlated with employee wellbeing, while job demands are negatively correlated with employee wellbeing. More recently the literature has examined the proposition in the work of Karasek and Theorell (1990) and Payne (1979) that organizational supports may mediate the association between job demands and employee wellbeing. This literature finds mixed support for the proposition. However, much less attention has been paid to the direct relationship between organizational support (irrespective of its mediating role) and the literature has paid only little attention to non-random selection of workers into jobs. We address both of these issues using linked employer-employee data for Finland.

In accordance with the theory job control and supervisory support are positively correlated with employee wellbeing and negatively correlated with job-related stress, while job demands are positively correlated with job-related stress. However, there is no association between job demands and employee wellbeing and, contrary to expectations, neither job control nor supervisory support alleviate the negative relationship between job demands and job-related stress. The direct effects of organizational support have, arguably, been underplayed in the literature, perhaps because most of that empirical literature is motivated by the Karasek (1979) and Karasek and Theorell (1990) models which focus primarily on job controls and demands, elaborating on the role of support primarily as a mediating factor. Our 
findings suggest the direct, independent role of organisational support is deserving of much greater attention.

The effects of organizational support are most pronounced in relation to supervisor support, are still apparent in most cases with respect to co-worker support, but are absent with respect to the support of clients and business partners. Future research is required to establish the mechanisms underpinning these different results.

Our results are relatively insensitive to the configuration of variables used to construct the items. ${ }^{15}$ Furthermore, the results are not sensitive to the incorporation of work histories data, suggesting worker selection into jobs of different types is not biasing the relationships described above. Our findings differ somewhat from those in the literature in two respects. First, we find no neither job control nor job support mediate the relationship between job demands and job-related stress. Second, although job demands are associated with greater job-related stress, they are not associated with lower employee wellbeing. One reason for these differences could be that ours is the first paper to present results for a country (Finland) where unionization rates are high - considerably higher than in the Anglo-US countries which feature heavily in the empirical literature. It may be that the influence of unions on the nature of job design, and the nature of social support at work, could affect the associations between worker wellbeing and job design. Second, our measures of job control, job demands and job support differ from other studies. However, the definition of these concepts tends to differ across most studies and, in any case, our survey measures are fairly complete compared to those featuring in other studies.

\footnotetext{
${ }^{15}$ Some of these sensitivity checks are reported in Appendix Tables A4 and A5. Others are available from the authors on request.
} 


\section{References}

Alasoini, T., Lyly-Yrjänäinen, M., Ramstad, E. and Heikkilä, A. (2014) "Innovativeness in Finnish workplaces. Renewing Working Life to Bring Finland to Bloom.” TEKES Review No. 312, Helsinki.

Artz, B.M., Goodall, A.H. and Oswald, A.J. (2016) "Boss Competence and Worker Wellbeing." Industrial and Labor Relations Review, 70, 419-450.

Barnow, B.S. and Smith, J. (2015) Employment and Training Programs. National Bureau of Economic Research, Working Paper \#21659.

Blanchflower, D. and Oswald, A. (2011) "International Happiness: A New View on the Measure of Performance.” Academy of Management Perspectives, 25, 6-22.

Böckerman, P., Bryson, A. and Ilmakunnas, P. (2013) “Does High Involvement Management Lead to Higher Pay?" Journal of the Royal Statistical Society: Series A Statistics in Society, 176, 861-885.

Böckerman, P., Bryson, A. and Ilmakunnas, P. (2012) "Does High Involvement Management Improve Worker Wellbeing?” Journal of Economic Behavior and Organization, 84, 660680.

Bryson, A., Erhel, C. and Salibekyan, Z. (2016) "Job Quality”, Chapter 6 in Amossé, T., Bryson, A., Forth, J. and Petit, H. (eds.) Comparative Workplace Employment Relations: An Analysis of Britain and France. London: Palgrave Macmillan, pp. 179-210.

Bryson, A., Forth, J. and Stokes, L. (2017) "Does Worker Wellbeing Affect Workplace Performance?", Human Relations, 70, 8, 1017-1037

Bryson, A. and MacKerron, G. (2017) “Are You Happy While You Work?” The Economic Journal, 127, 599: 106-125 
Clark, A.E., Diener, E., Georgellis, Y. and Lucas, R.E. (2008) "Lags and Leads in Life Satisfaction: A Test of the Baseline Hypothesis.” The Economic Journal, 118, F222-243.

Clark, A.E. and Oswald, A.J. (1996) "Satisfaction and Comparison Income." Journal of Public Economics, 61, 359-81.

Clark, A.E., Georgellis, Y. and Sanfey, P. (2001) "Scarring: The Psychological Impact of Past Unemployment.” Economica, 68, 221-241.

Cottini, E., Kato, T. and Westergaard-Nielsen, N. (2011) “Adverse Workplace Conditions, High-involvement Work Practices and Labor Turnover: Evidence from Danish Linked Employer-employee Data.” Labour Economics, 18, 872-80.

Gimeno, D., Benavides, F.G., Benach, J. and Amick, B.C. (2004) "Distribution of sickness absence in the European Union countries." Occupational and Environmental Medicine, $61,211-227$.

Godard, J. (2004) “A Critical Assessment of the High-performance Paradigm.” British Journal of Industrial Relations, 42, 349-378.

de Lange, A.H., Taris, T.W., Kompier, A.J., Houtman, I.L.D. and Bongers, P.M. (2003) “The Very Best of the Millennium: Longitudinal Research and the Demand Control (Support) Model.” Journal of Occupational Health Psychology, 8, 282-305.

Johnson, J.V. and Hall, E.M. (1988) "Job Strain, Work Place Social Support and Cardiovascular Disease: A Cross-section Study of a Random Sample of the Swedish Working Population.” American Journal of Public Health, 78, 1336-1342.

Jovanovic, B. (1979) “Job Matching and the Theory of Turnover." Journal of Political Economy, 87, 972-990.

Kahneman, D., Krueger, A.B., Schkade, D.A., Schwarz, N. and Stone, A.A. (2004) “A Survey Method for Characterizing Daily Life Experience: The Day Reconstruction Method." Science, 306, 1776-80. 
Karasek, R. (1979) “Job Demands, Job Decision Latitude and Mental Strain: Implications for Job Redesign.” Administrative Science Quarterly, 24, 285-308

Karasek, R. and Theorell, T. (1990) Healthy Work. New York: Basic Books

Landsberger, P., Schnall, P., Deitz, D., Friedman, R., and Pickering, T. (1992) "The Patterning of Psychological Attributes and Distress by 'Job Strain' and Social Support in a Sample of Working Men.” Journal of Behavioral Medicine, 15, 379-405.

Lazear, E.P. (2000) "Unresolved Issues in Personnel Economics: The Power of Incentives." American Economic Review: Papers and Proceedings, 90, 410-414.

Meadow Consortium (2010) "The MEADOW Guidelines, Project Funded within the 6th Framework Programme of the European Commission's DG Research”, Grigny, France.

Available at: http://www.meadowproject.eu/doc/users/307/bib/meadowguidelinespdf_7701.pdf

Minkkinen, J., Aho, S. and Mäkiaho, A. (2013) "Organisaatioiden ja työn dynamiikka työntekijöiden näkökulmasta: MEADOW-tutkimuksen II väliraportti”, Tekesin katsaus 300/2013. Helsinki: Tekes.

Payne, R.L. (1979) “Demands, Supports, Constraints and Psychological Health", in C.J. Mackay and Cox, T. (eds.) In Response to Stress: Occupational Aspects. London: IPC Business Press, pp. 85-105.

Payne, R.L. and Fletcher, B. (1983) “Job Demands, Supports and Constraints as Predictors of Psychological Strain among School Teachers." Journal of Vocational Behaviour, 22, $136-147$.

Plug, E., Webbink, D. and Martin, N. (2014) "Sexual Orientation, Prejudice and Segregation." Journal of Labor Economics, 32, 123-159.

Sargent, L.D. and Terry, D.J. (2000) “The Moderating Role of Social Support in Karasek's Job Strain Model.”Work and Stress, 14, 245-261. 
Smith, A. (1776) An Inquiry into the Nature and Causes of the Wealth of Nations. London. van der Doef, M. and Maes, S. (1999) "The Job Demand-Control (Support) Model and Psychological Wellbeing: A Review of 20 Years of Empirical Research." Work and Stress, 13, 87-114.

van Wanrooy, B., Bewley, H., Bryson, A., Forth, J., Stokes, L. and Wood, S. (2013) Employment Relations in the Shadow of Recession: Findings from the 2011 Workplace Employment Relations Study. London: Palgrave MacMillan.

Warr P. (2011) Work, Happiness and Unhappiness. London: Lawrence Erlbaum.

Wood, S. (2008) "Job characteristics, employee voice and wellbeing in Britain.” Industrial Relations Journal, 39, 153-168. 


\section{Tables}

Table 1: Summary statistics

\begin{tabular}{|c|c|c|}
\hline Variable & Mean & Std. Dev. \\
\hline \multicolumn{3}{|l|}{ Outcomes } \\
\hline Wellbeing & 0.00 & 1.00 \\
\hline Stress & 2.32 & 0.98 \\
\hline \multicolumn{3}{|c|}{ Job Control, Job Demands, Support } \\
\hline Job control & 0.00 & 1.00 \\
\hline Content & 2.54 & 0.92 \\
\hline Pace & 2.56 & 0.92 \\
\hline Order & 2.18 & 0.95 \\
\hline Distribution of work & 2.90 & 0.96 \\
\hline Job demands & 0.00 & 1.00 \\
\hline Thight deadlines & 2.87 & 0.91 \\
\hline Having to work at home & 1.66 & 0.72 \\
\hline Working outside actual hours of work & 2.94 & 1.02 \\
\hline Being contacted outside usual hours of work & 3.07 & 0.93 \\
\hline Average overtime hours & 8.99 & 9.72 \\
\hline Supervisor support & 0.41 & 0.49 \\
\hline Coworker support & 0.64 & 0.48 \\
\hline Client or cooperation partner support & 0.18 & 0.38 \\
\hline \multicolumn{3}{|l|}{ Control variables } \\
\hline Log annual earnings & 10.48 & 0.36 \\
\hline Age & 44.02 & 11.37 \\
\hline Female & 0.44 & 0.50 \\
\hline \multicolumn{3}{|l|}{ Level of education } \\
\hline Lower Secondary & 0.13 & 0.34 \\
\hline Upper secondary & 0.52 & 0.50 \\
\hline Short-cycle tertiary & 0.13 & 0.33 \\
\hline Bachelor's or equivalent & 0.13 & 0.34 \\
\hline Master's or equivalent & 0.08 & 0.27 \\
\hline Doctoral or equivalent & 0.01 & 0.08 \\
\hline Tenure & 10.09 & 8.31 \\
\hline \multicolumn{3}{|l|}{ Job history } \\
\hline Log average income in the past ten years & 7.72 & 0.58 \\
\hline Unemployment during the past ten years & 0.34 & 0.82 \\
\hline Average wage growth during the last ten years & 0.16 & 0.33 \\
\hline
\end{tabular}

Notes: $\mathrm{N}=1563$ for all variables in the table. For the job demands and job control scales the summary statistics for the components are also shown. The detailed questions can be found in the appendix. 
Table 2: Job control, Job demands and supervisor support

\begin{tabular}{|c|c|c|c|c|c|c|c|c|c|c|}
\hline & (1) & (2) & (3) & (4) & (5) & (6) & (7) & (8) & (9) & (10) \\
\hline & Wellbeing & Wellbeing & Wellbeing & Wellbeing & Wellbeing & Stress & Stress & Stress & Stress & Stress \\
\hline \multirow{2}{*}{ Job control scale } & $0.338 * * *$ & & & $0.290 * * *$ & $0.288 * * *$ & $-0.118^{*}$ & & & $-0.131 * *$ & $-0.130 * *$ \\
\hline & (8.071) & & & (6.322) & (6.224) & $(-2.374)$ & & & $(-2.835)$ & $(-2.879)$ \\
\hline \multirow[t]{2}{*}{ Job demands scale } & & 0.055 & & 0.032 & 0.033 & & $0.405 * * *$ & & $0.414 * * *$ & $0.418^{* * *}$ \\
\hline & & $(1.063)$ & & $(0.693)$ & $(0.703)$ & & (8.915) & & (9.665) & (9.940) \\
\hline \multirow[t]{2}{*}{ Supervisor support=1 } & & & $0.547^{* * *}$ & $0.435 * * *$ & $0.441 * * *$ & & & $-0.325 * * *$ & $-0.246 * *$ & $-0.248^{* *}$ \\
\hline & & & (6.147) & $(4.952)$ & (4.974) & & & $(-3.761)$ & $(-3.055)$ & $(-3.081)$ \\
\hline \multirow[t]{2}{*}{ Age } & 0.002 & -0.003 & 0.007 & 0.008 & 0.018 & $0.076^{*}$ & $0.070^{*}$ & $0.072^{*}$ & $0.064^{*}$ & 0.034 \\
\hline & $(0.073)$ & $(-0.102)$ & $(0.269)$ & $(0.305)$ & $(0.576)$ & $(2.570)$ & $(2.382)$ & (2.423) & $(2.241)$ & (1.038) \\
\hline \multirow[t]{2}{*}{ Age squared } & 0.000 & 0.000 & -0.000 & -0.000 & -0.000 & $-0.001 * *$ & $-0.001^{*}$ & $-0.001^{*}$ & $-0.001^{*}$ & -0.000 \\
\hline & $(0.255)$ & (0.329) & $(-0.099)$ & $(-0.028)$ & $(-0.325)$ & $(-2.656)$ & $(-2.339)$ & $(-2.445)$ & $(-2.215)$ & $(-1.156)$ \\
\hline \multirow[t]{2}{*}{ Female } & $0.235^{*}$ & $0.230^{*}$ & $0.241 *$ & $0.267^{* *}$ & $0.260 * *$ & 0.191 & $0.342 * * *$ & 0.181 & $0.322 * * *$ & $0.343 * * *$ \\
\hline & $(2.420)$ & (2.168) & (2.392) & $(2.781)$ & $(2.706)$ & $(1.946)$ & (3.894) & $(1.831)$ & (3.616) & (3.836) \\
\hline \multirow[t]{2}{*}{ Upper secondary } & -0.040 & -0.183 & -0.146 & -0.038 & -0.043 & 0.177 & 0.186 & 0.207 & 0.118 & 0.113 \\
\hline & $(-0.286)$ & $(-1.180)$ & $(-0.965)$ & $(-0.277)$ & $(-0.316)$ & $(1.278)$ & $(1.571)$ & $(1.511)$ & $(0.924)$ & $(0.900)$ \\
\hline \multirow[t]{2}{*}{ Short-cycle tertiary } & -0.098 & -0.255 & -0.218 & -0.102 & -0.113 & 0.098 & 0.085 & 0.133 & 0.013 & -0.002 \\
\hline & $(-0.563)$ & $(-1.345)$ & $(-1.239)$ & $(-0.626)$ & $(-0.698)$ & $(0.540)$ & $(0.532)$ & $(0.738)$ & $(0.079)$ & $(-0.010)$ \\
\hline \multirow[t]{2}{*}{ Bachelor's or equivalent } & -0.317 & $-0.421^{*}$ & $-0.422^{*}$ & -0.334 & -0.333 & 0.259 & 0.288 & 0.296 & 0.249 & 0.218 \\
\hline & $(-1.642)$ & $(-2.081)$ & $(-2.254)$ & $(-1.866)$ & $(-1.836)$ & $(1.314)$ & (1.684) & $(1.550)$ & $(1.464)$ & $(1.275)$ \\
\hline \multirow[t]{2}{*}{ Master's or equivalent } & $-0.523^{*}$ & $-0.629 *$ & $-0.639 * *$ & $-0.546^{*}$ & $-0.564 * *$ & 0.194 & 0.228 & 0.237 & 0.192 & 0.184 \\
\hline & $(-2.295)$ & $(-2.417)$ & $(-2.721)$ & $(-2.554)$ & $(-2.634)$ & $(0.911)$ & (1.244) & (1.129) & $(1.035)$ & (0.998) \\
\hline \multirow[t]{2}{*}{ Doctoral or equivalent } & 0.264 & 0.140 & 0.124 & 0.194 & 0.193 & 0.037 & -0.167 & 0.098 & -0.186 & -0.204 \\
\hline & $(0.624)$ & $(0.350)$ & $(0.232)$ & $(0.391)$ & $(0.385)$ & (0.139) & $(-0.468)$ & $(0.333)$ & $(-0.452)$ & $(-0.506)$ \\
\hline \multirow[t]{2}{*}{ Tenure } & -0.021 & -0.011 & -0.006 & -0.016 & -0.012 & -0.003 & -0.007 & -0.009 & -0.005 & -0.007 \\
\hline & $(-1.255)$ & $(-0.596)$ & $(-0.350)$ & $(-0.961)$ & $(-0.698)$ & $(-0.158)$ & $(-0.457)$ & $(-0.539)$ & $(-0.359)$ & $(-0.425)$ \\
\hline \multirow[t]{2}{*}{ Tenure squared } & 0.000 & 0.000 & 0.000 & 0.000 & 0.000 & 0.000 & 0.000 & 0.000 & 0.000 & 0.000 \\
\hline & $(0.854)$ & $(0.422)$ & (0.249) & $(0.715)$ & $(0.541)$ & (0.091) & $(0.627)$ & $(0.323)$ & $(0.566)$ & (0.639) \\
\hline
\end{tabular}


Log annual earnings
0.217

(1.710)
$0.298 *$

(2.054)

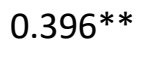

(2.911)
$0.258 *$

(1.970)
$0.340 *$

(2.014)

$-0.065$

$(-0.600)$

0.041

(0.981)

0.047

(0.333)

$$
\begin{array}{lll}
-0.003 & -0.331^{* *} & -0.080 \\
(-0.018) & (-2.581) & (-0.541)
\end{array}
$$

$(-0.018)$

$-0.317 *$

$(-2.425)$

$-0.378^{*}$

$(-2.119)$

0.106

(0.770)

0.034

(0.744)

\begin{tabular}{|c|c|c|c|c|c|c|c|c|c|c|}
\hline Adjusted R-squared & 0.248 & 0.151 & 0.218 & 0.289 & 0.290 & 0.095 & 0.204 & 0.108 & 0.240 & 0.242 \\
\hline Observations & 1563 & 1563 & 1563 & 1563 & 1563 & 1563 & 1563 & 1563 & 1563 & 1563 \\
\hline
\end{tabular}

$-0.159$

$(-0.968)$

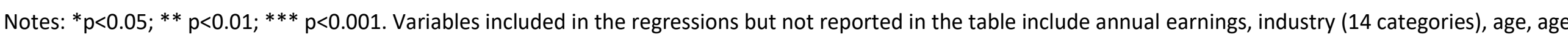
squared, tenure, tenure squared, female, level of education (5 categories) and occupation (38 categories). 
Table 3 Job control, Job demands and Supervisor support w/ interactions

\begin{tabular}{|c|c|c|c|c|c|c|}
\hline & $(1)$ & $(2)$ & (3) & (4) & $(5)$ & $(6)$ \\
\hline & Wellbeing & Wellbeing & Wellbeing & Stress & Stress & Stress \\
\hline \multirow[t]{2}{*}{ Job control scale } & $0.288 * * *$ & $0.272 * * *$ & $0.267 * * *$ & -0.098 & -0.102 & -0.098 \\
\hline & (4.019) & $(4.732)$ & (4.637) & $(-1.425)$ & $(-1.685)$ & $(-1.648)$ \\
\hline \multirow[t]{2}{*}{ Job demands scale } & 0.012 & 0.055 & 0.057 & $0.359 * * *$ & $0.414 * * *$ & $0.418^{* * *}$ \\
\hline & $(0.214)$ & $(0.865)$ & $(0.898)$ & (6.297) & (7.688) & (7.874) \\
\hline \multirow[t]{2}{*}{ Job control scale \# Job demands scale } & 0.048 & 0.057 & 0.057 & -0.022 & -0.058 & -0.058 \\
\hline & $(0.885)$ & $(1.202)$ & $(1.188)$ & $(-0.336)$ & $(-1.109)$ & $(-1.116)$ \\
\hline \multirow[t]{2}{*}{ Supervisor support=1 } & $0.414 * * *$ & $0.451 * * *$ & $0.458 * * *$ & $-0.207^{*}$ & $-0.245^{* *}$ & $-0.247 * *$ \\
\hline & $(4.389)$ & $(5.044)$ & $(5.076)$ & $(-2.429)$ & $(-3.040)$ & $(-3.060)$ \\
\hline \multirow[t]{2}{*}{ Supervisor support=1 \# Job control scale } & 0.087 & 0.027 & 0.033 & -0.043 & -0.051 & -0.061 \\
\hline & $(0.783)$ & $(0.274)$ & $(0.336)$ & $(-0.485)$ & $(-0.646)$ & $(-0.804)$ \\
\hline \multirow[t]{2}{*}{ Supervisor support=1 \# Job demands scale } & 0.027 & -0.023 & -0.025 & 0.011 & 0.014 & 0.011 \\
\hline & $(0.334)$ & $(-0.280)$ & $(-0.301)$ & $(0.133)$ & $(0.183)$ & $(0.158)$ \\
\hline \multirow[t]{2}{*}{ Supervisor support=1 \# Job control scale \# Job demands scale } & -0.063 & -0.086 & -0.092 & -0.042 & -0.010 & -0.002 \\
\hline & $(-0.930)$ & $(-1.235)$ & $(-1.329)$ & $(-0.480)$ & $(-0.127)$ & $(-0.031)$ \\
\hline \multirow[t]{2}{*}{ Age } & & 0.008 & 0.019 & & $0.063^{*}$ & 0.034 \\
\hline & & $(0.285)$ & $(0.598)$ & & $(2.231)$ & $(1.035)$ \\
\hline \multirow[t]{2}{*}{ Age squared } & & -0.000 & -0.000 & & $-0.001 *$ & -0.000 \\
\hline & & $(-0.027)$ & $(-0.357)$ & & $(-2.184)$ & $(-1.134)$ \\
\hline \multirow[t]{2}{*}{ Female } & & $0.273 * *$ & $0.265^{* *}$ & & $0.322 * * *$ & $0.343^{* * *}$ \\
\hline & & $(2.818)$ & $(2.734)$ & & (3.698) & $(3.908)$ \\
\hline \multirow[t]{2}{*}{ Upper secondary } & & -0.043 & -0.049 & & 0.127 & 0.121 \\
\hline & & $(-0.315)$ & $(-0.358)$ & & $(1.002)$ & $(0.975)$ \\
\hline \multirow[t]{2}{*}{ Short-cycle tertiary } & & -0.109 & -0.120 & & 0.017 & 0.002 \\
\hline & & $(-0.660)$ & $(-0.736)$ & & $(0.102)$ & $(0.010)$ \\
\hline \multirow[t]{2}{*}{ Bachelor's or equivalent } & & -0.341 & -0.340 & & 0.248 & 0.217 \\
\hline & & $(-1.880)$ & $(-1.849)$ & & $(1.453)$ & $(1.259)$ \\
\hline
\end{tabular}


Master's or equivalent

Doctoral or equivalent

Tenure

Tenure squared

Log annual earnings

Log average income in the past ten years

Unemployment during the past ten years

Wage growth during the past ten years

Adjusted R-squared

Observations

0.176

1563

Notes: ${ }^{*}<<0.05 ; * * p<0.01 ; * * * p<0.001$. Variables included in the regressions but not reported in the table include industry (14 categories) and occupation (38 categories).

\begin{tabular}{|c|c|c|c|c|}
\hline$-0.557^{* *}$ & $-0.577^{* *}$ & & 0.193 & 0.185 \\
\hline$(-2.583)$ & $(-2.668)$ & & (1.029) & (0.992) \\
\hline 0.160 & 0.157 & & -0.185 & -0.203 \\
\hline (0.338) & $(0.329)$ & & $(-0.465)$ & $(-0.521)$ \\
\hline-0.015 & -0.011 & & -0.004 & -0.005 \\
\hline$(-0.911)$ & $(-0.627)$ & & $(-0.280)$ & $(-0.358)$ \\
\hline 0.000 & 0.000 & & 0.000 & 0.000 \\
\hline$(0.702)$ & $(0.507)$ & & $(0.417)$ & (0.507) \\
\hline $0.266^{*}$ & $0.356^{*}$ & & $-0.296^{*}$ & -0.348 \\
\hline \multirow[t]{7}{*}{ (2.029) } & (2.103) & & $(-2.253)$ & $(-1.958)$ \\
\hline & -0.073 & & & 0.095 \\
\hline & $(-0.669)$ & & & $(0.687)$ \\
\hline & 0.042 & & & 0.035 \\
\hline & $(0.994)$ & & & $(0.765)$ \\
\hline & 0.050 & & & -0.165 \\
\hline & $(0.356)$ & & & $(-0.994)$ \\
\hline 0.289 & 0.290 & 0.154 & 0.242 & 0.244 \\
\hline 1563 & 1563 & 1563 & 1563 & 1563 \\
\hline
\end{tabular}


Table 4: Job control, Job demands and Colleague support w/ interactions

\begin{tabular}{|c|c|c|c|c|c|c|}
\hline & (1) & (2) & (3) & (4) & (5) & (6) \\
\hline & Wellbeing & Wellbeing & Wellbeing & Stress & Stress & Stress \\
\hline \multirow[t]{2}{*}{ Job control scale } & $0.410 * * *$ & $0.376 * * *$ & $0.375 * * *$ & -0.078 & -0.100 & -0.097 \\
\hline & $(4.446)$ & $(4.650)$ & $(4.693)$ & $(-0.804)$ & $(-1.075)$ & $(-1.059)$ \\
\hline \multirow[t]{2}{*}{ Job demands scale } & 0.006 & 0.047 & 0.049 & $0.261 * * *$ & $0.350 * * *$ & $0.356 * * *$ \\
\hline & $(0.086)$ & $(0.678)$ & $(0.705)$ & $(3.428)$ & $(5.030)$ & (5.169) \\
\hline \multirow[t]{2}{*}{ Job control scale \# Job demands scale } & -0.003 & -0.010 & -0.010 & -0.047 & -0.057 & -0.057 \\
\hline & $(-0.043)$ & $(-0.173)$ & $(-0.173)$ & $(-0.621)$ & $(-0.826)$ & $(-0.844)$ \\
\hline \multirow[t]{2}{*}{ Colleague support=1 } & 0.171 & 0.086 & 0.092 & $-0.214^{*}$ & $-0.198 *$ & $-0.203^{*}$ \\
\hline & $(1.814)$ & (0.948) & (0.999) & $(-2.232)$ & $(-2.348)$ & $(-2.397)$ \\
\hline \multirow[t]{2}{*}{ Colleague support=1 \# Job control scale } & -0.070 & -0.062 & -0.063 & -0.074 & -0.063 & -0.066 \\
\hline & $(-0.616)$ & $(-0.637)$ & $(-0.648)$ & $(-0.668)$ & $(-0.642)$ & $(-0.675)$ \\
\hline \multirow[t]{2}{*}{ Colleague support=1 \# Job demands scale } & 0.005 & -0.037 & -0.038 & 0.155 & 0.103 & 0.099 \\
\hline & $(0.058)$ & $(-0.467)$ & $(-0.482)$ & $(1.796)$ & $(1.332)$ & $(1.298)$ \\
\hline \multirow[t]{2}{*}{ Colleague support=1 \# Job control scale \# Job demands scale } & 0.016 & 0.020 & 0.017 & 0.001 & -0.009 & -0.003 \\
\hline & $(0.228)$ & $(0.282)$ & $(0.231)$ & $(0.009)$ & $(-0.109)$ & $(-0.035)$ \\
\hline \multirow[t]{2}{*}{ Age } & & 0.006 & 0.014 & & $0.059 *$ & 0.030 \\
\hline & & (0.211) & $(0.441)$ & & (1.998) & $(0.884)$ \\
\hline \multirow[t]{2}{*}{ Age squared } & & 0.000 & -0.000 & & $-0.001^{*}$ & -0.000 \\
\hline & & $(0.126)$ & $(-0.146)$ & & $(-1.985)$ & $(-1.007)$ \\
\hline \multirow[t]{2}{*}{ Female } & & $0.239 *$ & $0.234^{*}$ & & $0.330 * * *$ & $0.350 * * *$ \\
\hline & & $(2.463)$ & $(2.403)$ & & $(3.737)$ & (3.932) \\
\hline \multirow[t]{2}{*}{ Upper secondary } & & -0.054 & -0.058 & & 0.135 & 0.129 \\
\hline & & $(-0.393)$ & $(-0.424)$ & & $(1.067)$ & $(1.036)$ \\
\hline \multirow[t]{2}{*}{ Short-cycle tertiary } & & -0.118 & -0.127 & & 0.044 & 0.029 \\
\hline & & $(-0.706)$ & $(-0.768)$ & & $(0.261)$ & $(0.178)$ \\
\hline \multirow[t]{2}{*}{ Bachelor's or equivalent } & & -0.311 & -0.308 & & 0.238 & 0.207 \\
\hline & & $(-1.635)$ & $(-1.584)$ & & $(1.343)$ & (1.159) \\
\hline
\end{tabular}


Master's or equivalent

Doctoral or equivalent

Tenure

Tenure squared

Log annual earnings

Log average income in the past ten years

Unemployment during the past ten years

Wage growth during the past ten years

Adjusted R-squared

Observations

Notes: ${ }^{*} p<0.05 ;{ }^{*} p<0.01 ; * * * p<0.001$. Variables included in the regressions but not reported in the table include industr

(14 categories) and occupation (38 categories).

\begin{tabular}{|c|c|c|c|c|}
\hline$-0.526^{*}$ & $-0.539 *$ & & 0.170 & 0.160 \\
\hline$(-2.280)$ & $(-2.326)$ & & $(0.895)$ & $(0.845)$ \\
\hline 0.244 & 0.244 & & -0.194 & -0.214 \\
\hline$(0.604)$ & (0.598) & & $(-0.564)$ & $(-0.632)$ \\
\hline-0.020 & -0.017 & & -0.002 & -0.003 \\
\hline$(-1.243)$ & $(-1.010)$ & & $(-0.125)$ & $(-0.193)$ \\
\hline 0.000 & 0.000 & & 0.000 & 0.000 \\
\hline$(0.859)$ & $(0.709)$ & & $(0.365)$ & $(0.442)$ \\
\hline 0.198 & 0.258 & & -0.256 & -0.307 \\
\hline \multirow[t]{7}{*}{$(1.467)$} & $(1.458)$ & & $(-1.883)$ & $(-1.680)$ \\
\hline & -0.047 & & & 0.095 \\
\hline & $(-0.397)$ & & & $(0.677)$ \\
\hline & 0.033 & & & 0.036 \\
\hline & $(0.707)$ & & & $(0.780)$ \\
\hline & 0.044 & & & -0.156 \\
\hline & $(0.297)$ & & & $(-0.920)$ \\
\hline 0.248 & 0.248 & 0.157 & 0.237 & 0.239 \\
\hline 1563 & 1563 & 1563 & 1563 & 1563 \\
\hline
\end{tabular}


Table 5: Job control, Job demands and Colleague support w/ interactions

\begin{tabular}{|c|c|c|c|c|c|c|}
\hline & $(1)$ & $(2)$ & (3) & (4) & (5) & $(6)$ \\
\hline & Wellbeing & Wellbeing & Wellbeing & Stress & Stress & Stress \\
\hline \multirow[t]{2}{*}{ Job control scale } & $0.352 * * *$ & $0.316 * * *$ & $0.315^{* * *}$ & $-0.162 * * *$ & $-0.170 * * *$ & $-0.171 * * *$ \\
\hline & $(6.051)$ & $(6.628)$ & $(6.613)$ & $(-3.368)$ & $(-4.171)$ & $(-4.335)$ \\
\hline \multirow[t]{2}{*}{ Job demands scale } & -0.000 & 0.027 & 0.026 & $0.347 * * *$ & $0.420 * * *$ & $0.424 * * *$ \\
\hline & $(-0.010)$ & $(0.498)$ & $(0.489)$ & (7.711) & (8.947) & (9.215) \\
\hline \multirow[t]{2}{*}{ Job control scale \# Job demands scale } & 0.012 & -0.007 & -0.009 & -0.075 & -0.078 & -0.076 \\
\hline & $(0.305)$ & $(-0.190)$ & $(-0.243)$ & $(-1.567)$ & $(-1.801)$ & $(-1.841)$ \\
\hline \multirow[t]{2}{*}{ Client or business partner support $=1$} & 0.051 & 0.001 & 0.002 & 0.097 & 0.125 & 0.127 \\
\hline & $(0.414)$ & $(0.008)$ & $(0.022)$ & $(0.966)$ & $(1.302)$ & $(1.308)$ \\
\hline \multirow[t]{2}{*}{ Client or business partner support=1 \# Job control scale } & 0.094 & 0.096 & 0.092 & 0.067 & 0.060 & 0.065 \\
\hline & $(0.741)$ & $(0.901)$ & $(0.860)$ & $(0.564)$ & $(0.480)$ & $(0.525)$ \\
\hline \multirow[t]{2}{*}{ Client or business partner support=1 \# Job demands scale } & -0.028 & -0.056 & -0.053 & 0.064 & -0.010 & -0.007 \\
\hline & $(-0.271)$ & $(-0.573)$ & $(-0.538)$ & $(0.806)$ & $(-0.129)$ & $(-0.095)$ \\
\hline \multicolumn{7}{|c|}{ Client or business partner support=1 \# Job control scale \# Job demands } \\
\hline \multirow[t]{2}{*}{ scale } & -0.004 & 0.047 & 0.047 & 0.130 & 0.079 & 0.081 \\
\hline & $(-0.049)$ & $(0.635)$ & (0.639) & $(1.421)$ & $(0.975)$ & $(1.008)$ \\
\hline \multirow[t]{2}{*}{ Age } & & 0.002 & 0.008 & & $0.064 *$ & 0.034 \\
\hline & & $(0.063)$ & $(0.248)$ & & $(2.217)$ & $(1.045)$ \\
\hline \multirow[t]{2}{*}{ Age squared } & & 0.000 & 0.000 & & $-0.001^{*}$ & -0.000 \\
\hline & & $(0.242)$ & $(0.021)$ & & $(-2.253)$ & $(-1.229)$ \\
\hline \multirow[t]{2}{*}{ Female } & & $0.243^{*}$ & $0.238^{*}$ & & $0.344 * * *$ & $0.362 * * *$ \\
\hline & & $(2.468)$ & $(2.402)$ & & (3.959) & $(4.124)$ \\
\hline \multirow[t]{2}{*}{ Upper secondary } & & -0.061 & -0.064 & & 0.108 & 0.099 \\
\hline & & $(-0.439)$ & $(-0.459)$ & & $(0.893)$ & $(0.837)$ \\
\hline \multirow[t]{2}{*}{ Short-cycle tertiary } & & -0.107 & -0.113 & & 0.017 & -0.002 \\
\hline & & $(-0.610)$ & $(-0.652)$ & & $(0.107)$ & $(-0.014)$ \\
\hline Bachelor's or equivalent & & -0.333 & -0.333 & & 0.219 & 0.184 \\
\hline
\end{tabular}




\begin{tabular}{|c|c|c|c|c|c|c|}
\hline & & $(-1.715)$ & $(-1.670)$ & & $(1.310)$ & $(1.085)$ \\
\hline \multirow[t]{2}{*}{ Master's or equivalent } & & $-0.535 *$ & $-0.546 *$ & & 0.175 & 0.162 \\
\hline & & $(-2.340)$ & $(-2.371)$ & & $(0.960)$ & $(0.893)$ \\
\hline \multirow[t]{2}{*}{ Doctoral or equivalent } & & 0.257 & 0.257 & & -0.196 & -0.216 \\
\hline & & $(0.627)$ & $(0.621)$ & & $(-0.569)$ & $(-0.640)$ \\
\hline \multirow[t]{2}{*}{ Tenure } & & -0.021 & -0.019 & & -0.003 & -0.003 \\
\hline & & $(-1.317)$ & $(-1.115)$ & & $(-0.195)$ & $(-0.223)$ \\
\hline \multirow[t]{2}{*}{ Tenure squared } & & 0.000 & 0.000 & & 0.000 & 0.000 \\
\hline & & $(0.940)$ & $(0.813)$ & & $(0.449)$ & $(0.501)$ \\
\hline \multirow[t]{2}{*}{ Log annual earnings } & & 0.208 & 0.265 & & -0.236 & -0.262 \\
\hline & & $(1.541)$ & $(1.458)$ & & $(-1.858)$ & $(-1.456)$ \\
\hline \multirow[t]{2}{*}{ Log average income in the past ten years } & & & -0.048 & & & 0.071 \\
\hline & & & $(-0.400)$ & & & $(0.488)$ \\
\hline \multirow[t]{2}{*}{ Unemployment during the past ten years } & & & 0.025 & & & 0.043 \\
\hline & & & $(0.547)$ & & & $(0.956)$ \\
\hline \multirow[t]{2}{*}{ Wage growth during the past ten years } & & & 0.024 & & & -0.179 \\
\hline & & & $(0.163)$ & & & $(-1.040)$ \\
\hline Adjusted R-squared & 0.137 & 0.248 & 0.247 & 0.151 & 0.232 & 0.234 \\
\hline Observations & 1563 & 1563 & 1563 & 1563 & 1563 & 1563 \\
\hline
\end{tabular}

Notes: ${ }^{*} p<0.05 ; * * p<0.01 ; * * p<0.001$. Variables included in the regressions but not reported in the table include industry (14 categories) and occupation (38 categories). 


\section{SUPPLEMENTARY ONLINE APPENDIX}

\section{Job control}

The measure of job control is based on the following questions

25. Do you have 1) a lot of, 2) a fair amount of, 3) some, 4) not at all influence on the following issues?

a. which tasks your work consists of

b. your working pace

c. in which order you carry out tasks

d. how tasks are distributed among employees at work

We form a standardized scale of questions Q25a Q25b Q25c Q25d (reversing the values so that higher values mean better control). The scale has Cronbach's alpha of 0.68 . Because the estimation use weights we further subtract the weighted mean and divide by the weighted standard deviation so that the scale has zero mean and standard deviation of 1 also in the estimations.

\section{Job demands}

We use the following questions to form a standardized scale

16. How often does your job involve working to tight deadlines or at very high speed?

1. Less than $25 \%$ of the time

2. $25 \%$ up to $50 \%$ of the time

3. $50 \%$ up to $75 \%$ of the time

4. $75 \%$ or more of the time

17. How often you carry out tasks related to your main job at home?

1. Never

2. Occasionally

3. Frequently

18. How often you carry out tasks related to your main outside your actual hours of work?

1. every day

2. at least once a week

3. at least once a month

4. less often than once a month/never

5. not applicable

19. How often are you contacted by phone or in person on work related matters outside your usual working hours?

1. Every day

2. At least once a week

3. At least once a month

4. Less often than once a month / never

42. Over the past $\mathbf{1 2}$ months how many hours per month have you worked overtime or done extra work during an average month?

The standardized scale is formed in the following way $Q 16+A 17+Q 18+Q 19+Q 42$. In the overtime question the number of overtime hours has been capped at 40 to reduce some very large values. This affects 31 observations. These items are quite highly correlated and the scale has a Cronbach's alpha of 0.73 . Because 
the estimations use weights we further subtract the weighted mean and divide by the weighted standard deviation so that the scale has zero mean and standard deviation of 1 also in the estimations.

\section{Job Support}

Job support is measured with a single question

13. In case of work overload or a difficult situation, do you receive assistance from

1. Always; 2 . Sometimes; 3. Never; 4. Not applicable
a. Your supervisor or manager
b. Your coworkers
c. Your clients or cooperation partners

We form three different measures of support.

Supervisor support $=1$ if $Q 13 a==1$ and 0 otherwise

Coworker support $=1$ if $Q 13 b==1$ and 0 otherwise

Client or cooperation partner support=1 if $Q 13 c==1$ and 0 otherwise

\section{Using the job control and job demands measures in regression instead of the scale variables}

To assess the sensitivity of the results to using the scales instead of the individual measures of job control and job demands, we estimated a regression where the dependent variable is overall job satisfaction and the independent variables include the individual components of the job demands and job control scales, supervisor support and the control variables that were used in Table 4 . The results show that i) the individual components of the job demands scale have statistically similar coefficients and they are not jointly different from zero, ii) the individual components of the job control scale have statistically similar coefficients and are jointly different from zero. These results match the results from a regression of job satisfaction on the job demands scale, job control scale, supervisor support and the control variables from Table 4. Together these results imply that the scales are a meaningful summary of the underlying variables. 
Table A1: Job Control, Job Demands, Job Support, and Labor market history

\begin{tabular}{|c|c|c|c|c|c|}
\hline & $\begin{array}{l}\text { Job control } \\
\text { scale }\end{array}$ & $\begin{array}{c}\text { Job } \\
\text { demands } \\
\text { scale }\end{array}$ & $\begin{array}{c}\text { Supervisor } \\
\text { support }\end{array}$ & $\begin{array}{l}\text { Colleague } \\
\text { support }\end{array}$ & $\begin{array}{l}\text { Client or } \\
\text { business } \\
\text { partner } \\
\text { support }\end{array}$ \\
\hline \multirow[t]{2}{*}{ Log average income in the past ten years } & -0.273 & -0.013 & 0.014 & 0.065 & 0.027 \\
\hline & $(-1.923)$ & $(-0.105)$ & $(0.176)$ & $(0.949)$ & $(0.696)$ \\
\hline \multirow[t]{2}{*}{ Unemployment during the past ten years } & 0.006 & -0.043 & -0.029 & -0.024 & -0.010 \\
\hline & $(0.112)$ & $(-0.829)$ & $(-1.151)$ & $(-0.934)$ & $(-0.461)$ \\
\hline \multirow[t]{2}{*}{ Wage growth during the last ten years } & -0.256 & 0.201 & -0.051 & -0.038 & 0.049 \\
\hline & $(-1.396)$ & $(1.275)$ & $(-0.528)$ & $(-0.483)$ & $(0.900)$ \\
\hline Adjusted $\mathrm{R}^{2}$ & 0.134 & 0.291 & 0.049 & 0.117 & 0.130 \\
\hline $\mathrm{N}$ & 1563 & 1563 & 1563 & 1563 & 1563 \\
\hline
\end{tabular}

Notes: ${ }^{*} p<0.05 ; * * p<0.01 ; * * * p<0.001$. Variables included in the regressions but not reported in the table include annual earnings, industry (14 categories), age, age squared, tenure, tenure squared, female, level of education (5 categories) and occupation (38 categories). 
Table A2: Job control, Job demands and support w/ additional control variables

Job control scale

Job demands scale

Job control scale \# Job demands scale

\section{Supervisor support=1}

Supervisor support=1 \# Job control scale

Supervisor support=1 \# Job demands scale

Supervisor support=1 \# Job control scale \# Job demands scale

Colleague support $=1$

Colleague support=1 \# Job control scale

Colleague support=1 \# Job demands scale

Colleague support=1 \# Job control scale \# Job demands scale

Client or business partner support $=1$

Client or business partner support=1 \# Job control scale

\begin{tabular}{|c|c|c|c|c|c|}
\hline (1) & (2) & (3) & (4) & (5) & (6) \\
\hline Wellbeing & Wellbeing & Wellbeing & Stress & Stress & Stress \\
\hline $0.267 * * *$ & $0.395 * * *$ & $0.323 * * *$ & -0.100 & -0.103 & $-0.181 * * *$ \\
\hline$(4.642)$ & (4.804) & (6.643) & $(-1.699)$ & $(-1.063)$ & $(-4.308)$ \\
\hline 0.069 & 0.026 & 0.034 & $0.417 * * *$ & $0.324 * * *$ & $0.423 * * *$ \\
\hline (1.100) & $(0.371)$ & $(0.642)$ & (7.857) & (4.719) & (8.798) \\
\hline 0.086 & 0.019 & 0.009 & -0.047 & -0.050 & -0.076 \\
\hline$(1.825)$ & $(0.323)$ & $(0.248)$ & $(-0.907)$ & $(-0.749)$ & $(-1.803)$ \\
\hline $0.447 * * *$ & & & $-0.242 * *$ & & \\
\hline$(4.846)$ & & & $(-2.938)$ & & \\
\hline 0.034 & & & -0.060 & & \\
\hline$(0.332)$ & & & $(-0.776)$ & & \\
\hline-0.048 & & & 0.028 & & \\
\hline$(-0.597)$ & & & $(0.381)$ & & \\
\hline-0.112 & & & -0.023 & & \\
\hline$(-1.576)$ & & & $(-0.295)$ & & \\
\hline & 0.070 & & & $-0.182^{*}$ & \\
\hline & $(0.747)$ & & & $(-2.105)$ & \\
\hline & -0.087 & & & -0.066 & \\
\hline & $(-0.875)$ & & & $(-0.627)$ & \\
\hline & -0.002 & & & $0.156^{*}$ & \\
\hline & $(-0.024)$ & & & (2.056) & \\
\hline & -0.004 & & & -0.012 & \\
\hline & $(-0.057)$ & & & $(-0.144)$ & \\
\hline & & 0.032 & & & 0.096 \\
\hline & & $(0.281)$ & & & $(0.988)$ \\
\hline & & 0.054 & & & 0.110 \\
\hline & & $(0.510)$ & & & $(0.917)$ \\
\hline
\end{tabular}


Client or business partner support=1 \# Job demands scale

Client or business partner support=1 \# Job control scale \# Job demands scale Age

Age squared

Female

Upper secondary

Short-cycle tertiary

Bachelor's or equivalent

Master's or equivalent

Doctoral or equivalent

Tenure

Tenure squared

Log annual earnings

Log average income in the past ten years

Unemployment during the past ten years

$\begin{array}{llllll} & & -0.092 & & & 0.015 \\ & & (-0.884) & & & (0.197) \\ & & 0.064 & & & 0.071 \\ & & (0.830) & & & (0.913) \\ 0.009 & 0.006 & 0.002 & 0.033 & 0.028 & 0.031 \\ (0.294) & (0.177) & (0.051) & (0.973) & (0.801) & (0.892) \\ -0.000 & 0.000 & 0.000 & -0.000 & -0.000 & -0.000 \\ (-0.027) & (0.159) & (0.247) & (-1.053) & (-0.900) & (-1.061) \\ 0.302^{* *} & 0.263^{* *} & 0.261^{* *} & 0.326^{* * *} & 0.332^{* * *} & 0.358^{* * *} \\ (3.172) & (2.730) & (2.671) & (3.736) & (3.798) & (4.004) \\ -0.089 & -0.096 & -0.102 & 0.147 & 0.159 & 0.122 \\ (-0.615) & (-0.669) & (-0.698) & (1.158) & (1.244) & (1.008) \\ -0.130 & -0.123 & -0.107 & 0.041 & 0.075 & 0.022 \\ (-0.777) & (-0.730) & (-0.604) & (0.253) & (0.456) & (0.139) \\ -0.377^{*} & -0.337 & -0.361 & 0.281 & 0.283 & 0.242 \\ (-1.969) & (-1.678) & (-1.758) & (1.637) & (1.582) & (1.422) \\ -0.613^{* *} & -0.562^{*} & -0.568^{*} & 0.222 & 0.207 & 0.191 \\ (-2.708) & (-2.355) & (-2.397) & (1.169) & (1.061) & (1.032) \\ 0.178 & 0.297 & 0.304 & -0.161 & -0.131 & -0.173 \\ (0.378) & (0.712) & (0.735) & (-0.399) & (-0.388) & (-0.494) \\ -0.016 & -0.023 & -0.023 & -0.004 & -0.002 & -0.003 \\ (-0.929) & (-1.296) & (-1.295) & (-0.239) & (-0.110) & (-0.183) \\ 0.000 & 0.000 & 0.000 & 0.000 & 0.000 & 0.000 \\ (0.753) & (0.898) & (0.911) & (0.368) & (0.351) & (0.454) \\ 0.387^{*} & 0.284 & 0.280 & -0.341 & -0.288 & -0.249 \\ (2.199) & (1.544) & (1.493) & (-1.841) & (-1.526) & (-1.318) \\ -0.081 & -0.061 & -0.066 & 0.091 & 0.090 & 0.073 \\ (-0.737) & (-0.510) & (-0.541) & (0.628) & (0.611) & (0.479) \\ 0.031 & 0.021 & 0.014 & 0.033 & 0.034 & 0.041 \\ & & & & & \end{array}$




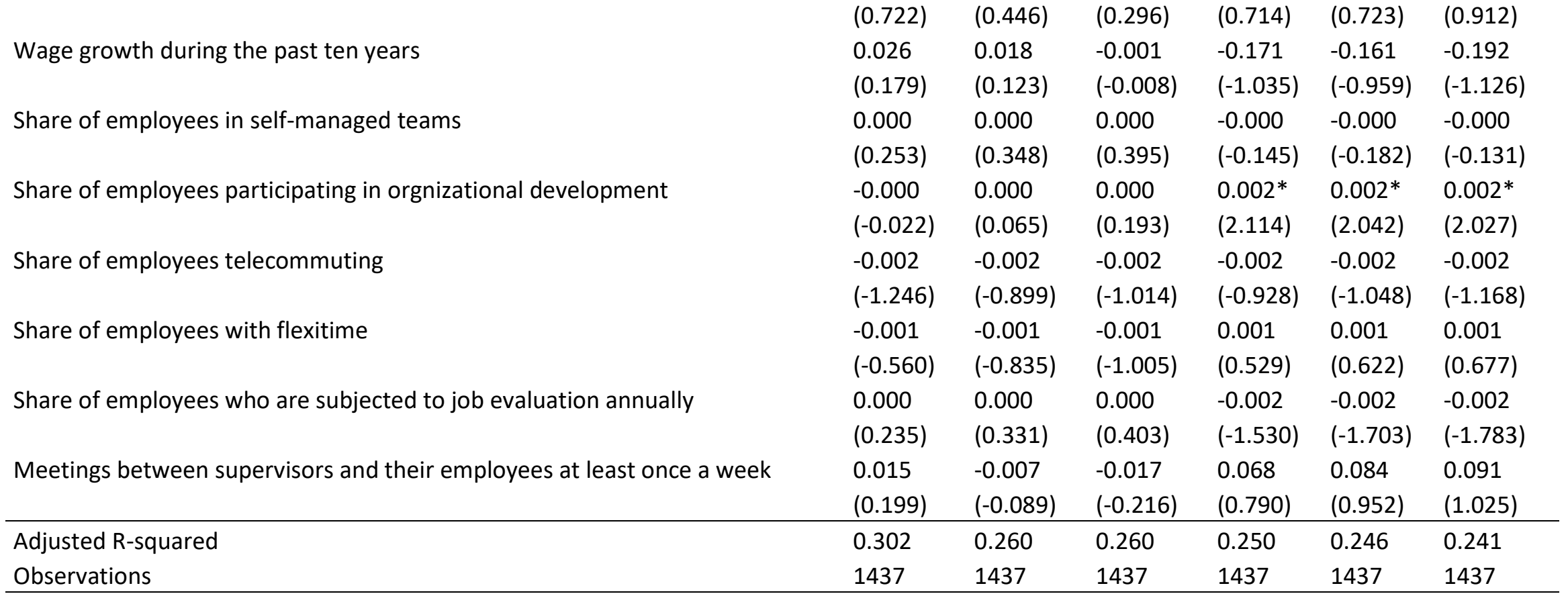

Notes: ${ }^{*} p<0.05 ; * *<<0.01 ; * * p<0.001$. Variables included in the regressions but not reported in the table include industry (14 categories) and occupation(38 categories). 
Table A3 :Prevalence of different combinations of Control Demand and Support

Job Control \#Job Demands\# Supervisor support

010

0.07

011

0.10

100

0.11

101

0.06

110

0.05

111

0.04

$\mathrm{N}$

1563 
Table A4: Job control, Job demands and supervisor support as dichotomous variables

Job demands $0 / 1$ based on the scale $=1$

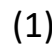

Job control $0 / 1$ based on the scale $=1$

(1) (2) (3)

$0.148 \quad 0.127 \quad 0.123$

(4)

(5)

(6)

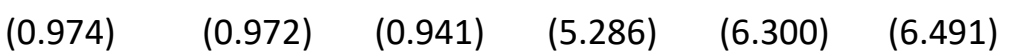

$\begin{array}{llllll}0.680 * * * & 0.594 * * * & 0.602 * * * & -0.198 & -0.139 & -0.150\end{array}$

Job demands $0 / 1$ based on the scale=1 \# Job control $0 / 1$ based on the scale=1

(3.534) (3.555) (-1.450) (-0.998) $\quad(-1.074)$

Supervisor support=1

$-0.290$

$0.037 \quad 0.022$

0.090

$-0.146-0.126$

$0.467^{* * *}$

$(0.148)$

(0.088)

(0.312)

$(-0.516) \quad(-0.445)$

Job demands $0 / 1$ based on the scale=1 \# Supervisor support=1

(3.337)

(3.983)

$0.512 *$

$-0.203$

$-0.232 *-0.229 *$

0.014

0.058

0.068

$(-1.632)$

$(-2.011) \quad(-2.009)$

(0.062)

(0.274)

(0.320)

.003

$-0.138-0.161$

Job control 0/1 based on the scale=1 \# Supervisor support=1

$-0.178$

$-0.169$

$-0.179$

(0.015)

$(-0.665) \quad(-0.791)$

$(-0.774)$

Job demands $0 / 1$ based on the scale=1 \# Job control 0/1 based on the scale=1 \# Supervisor support=1

(1.201)

\section{Age}

$(-0.781)$

$-0.057$

$(-0.823)$

$-0.119$

$-0.134$

$(-0.607)$

$(-0.688) \quad(-0.657)$

0.004

$(-0.171)$

$(-0.186)$

0.143

0.138

$0.004 \quad 0.020$

(0.165) (0.634)

$0.000 \quad-0.000$

(0.072) (-0.390)

\section{Female}

Upper secondary

$0.280 * * \quad 0.267 * *$

(2.888) (2.780)

$-0.058-0.062$

$(-0.411) \quad(-0.439)$

$-0.133 \quad-0.141$

$(-0.802) \quad(-0.861)$

$-0.384^{*}-0.378^{*}$

$(-2.071) \quad(-2.028)$

$-0.567^{*}-0.582^{*}$

(0.352)

$0.067^{*}$

(2.292)

(0.342)

$(-2.286) \quad(-1.226)$

$0.308^{* * *} \quad 0.336 * * *$

(3.407) (3.672)

$0.123 \quad 0.119$

(0.911) (0.891)

$0.025 \quad 0.015$

(0.140) (0.084)

$0.222 \quad 0.199$

(1.228) (1.081)

Master's or equivalent 
Doctoral or equivalent

Tenure

Tenure squared

Log annual earnings

Log average income in the past ten years

Unemployment during the past ten years

Wage growth during the past ten years

Adjusted R-squared

0.132

1563

Observations

Notes: ${ }^{*} p<0.05 ; * * p<0.01 ; * * * p<0.001$. Variables included in the regressions but not reported in

the table include industry (14 categories) and occupation (38 categories).

$(-2.505) \quad(-2.578)$

$0.319 \quad 0.321$

(0.604) (0.604)

$-0.011-0.007$

$(-0.713) \quad(-0.430)$

$0.000 \quad 0.000$

(0.404) (0.207)

$0.302 * 0.406$ *

(2.229)
(2.368)

$-0.099$

$(-0.895)$

0.037

(0.816)

0.063

(0.447)

0.268

(0.902) (0.874)

$-0.068-0.084$

$(-0.180) \quad(-0.225)$

$-0.006 \quad-0.008$

$(-0.384) \quad(-0.512)$

$0.000 \quad 0.000$

(0.341) (0.467)

$-0.179 \quad-0.284$

$(-1.345) \quad(-1.499)$

0.159

(1.048)

0.025

(0.524)

$-0.104$

(-0.599)

$1563 \quad 1563$

0.192

1563 


\begin{tabular}{|c|c|c|}
\hline & (1) & $(2)$ \\
\hline & Wellbeing & Stress \\
\hline \multirow[t]{2}{*}{ Job control scale } & $0.289 * * *$ & $-0.131 * *$ \\
\hline & (6.285) & $(-3.016)$ \\
\hline \multirow[t]{2}{*}{ Job demands scale } & 0.032 & $0.400 * * *$ \\
\hline & $(0.707)$ & (9.577) \\
\hline \multirow[t]{2}{*}{ Supervisor support=1 } & $0.456 * * *$ & $-0.226 * *$ \\
\hline & $(5.064)$ & $(-2.832)$ \\
\hline \multirow[t]{2}{*}{ Colleague support=1 } & -0.034 & -0.160 \\
\hline & $(-0.376)$ & $(-1.861)$ \\
\hline \multirow[t]{2}{*}{ Client or business partner support=1 } & -0.058 & $0.221 *$ \\
\hline & $(-0.555)$ & $(1.971)$ \\
\hline \multirow[t]{2}{*}{ Age } & 0.018 & 0.024 \\
\hline & $(0.564)$ & $(0.755)$ \\
\hline \multirow[t]{2}{*}{ Age squared } & -0.000 & -0.000 \\
\hline & $(-0.300)$ & $(-0.947)$ \\
\hline \multirow[t]{2}{*}{ Female } & $0.260 * *$ & $0.350 * * *$ \\
\hline & $(2.695)$ & (3.915) \\
\hline \multirow[t]{2}{*}{ Upper secondary } & -0.039 & 0.115 \\
\hline & $(-0.293)$ & $(0.928)$ \\
\hline \multirow[t]{2}{*}{ Short-cycle tertiary } & -0.110 & 0.032 \\
\hline & $(-0.690)$ & $(0.200)$ \\
\hline \multirow[t]{2}{*}{ Bachelor's or equivalent } & -0.337 & 0.214 \\
\hline & $(-1.849)$ & $(1.251)$ \\
\hline \multirow[t]{2}{*}{ Master's or equivalent } & $-0.573^{* *}$ & 0.194 \\
\hline & $(-2.661)$ & $(1.055)$ \\
\hline \multirow[t]{2}{*}{ Doctoral or equivalent } & 0.179 & -0.207 \\
\hline & $(0.360)$ & $(-0.521)$ \\
\hline
\end{tabular}




\begin{tabular}{lll} 
Tenure & -0.012 & -0.009 \\
& $(-0.675)$ & $(-0.565)$ \\
Tenure squared & 0.000 & 0.000 \\
& $(0.506)$ & $(0.831)$ \\
Log annual earnings & $0.331^{*}$ & $-0.343^{*}$ \\
& $(1.965)$ & $(-1.985)$ \\
Log average income in the past ten years & -0.061 & 0.110 \\
& $(-0.553)$ & $(0.808)$ \\
Unemployment during the past ten years & 0.041 & 0.032 \\
& $(0.956)$ & $(0.721)$ \\
Wage growth during the past ten years & 0.050 & -0.171 \\
& $(0.356)$ & $(-1.064)$ \\
\hline Adjusted R-squared & 0.289 & 0.251 \\
Supervisor=Colleague & 0.000 & 0.578 \\
Supervisor=Client or business partner & 0.000 & 0.003 \\
Observations & 1563 & 1563 \\
\hline
\end{tabular}

Notes: ${ }^{*} p<0.05 ;{ }^{* *} p<0.01 ;{ }^{* * *} p<0.001$. Variables included in the regressions but not reported in the table include industry (14

categories) and occupation (38 categories). 
Table A6: Different measures of Job Demands

\begin{tabular}{|c|c|c|c|c|c|c|c|c|c|c|}
\hline & (1) & (2) & (3) & (4) & (5) & (6) & (7) & (8) & (9) & (10) \\
\hline & Wellbeing & Wellbeing & Wellbeing & Wellbeing & Wellbeing & Stress & Stress & Stress & Stress & Stress \\
\hline \multirow[t]{2}{*}{ Job demands scale } & 0.032 & & & & & $0.414 * * *$ & & & & \\
\hline & $(0.693)$ & & & & & (9.665) & & & & \\
\hline \multirow[t]{2}{*}{ Job demands $0 / 1$ based on the scale } & & 0.136 & & & & & $0.726 * * *$ & & & \\
\hline & & $(1.420)$ & & & & & (7.506) & & & \\
\hline \multirow[t]{2}{*}{ Job demands $0 / 1$} & & & $0.176^{*}$ & & & & & $0.270 * *$ & & \\
\hline & & & $(2.217)$ & & & & & $(3.005)$ & & \\
\hline \multirow[t]{2}{*}{ Job demands based on Q16 Q18 and Q41c } & & & & 0.097 & & & & & $0.419 * * *$ & \\
\hline & & & & $(1.641)$ & & & & & (6.338) & \\
\hline \multirow[t]{2}{*}{ difference } & & & & & $-0.142 * * *$ & & & & & $0.261^{* * *}$ \\
\hline & & & & & $(-3.928)$ & & & & & $(8.385)$ \\
\hline \multirow[t]{2}{*}{ Job control scale } & $0.290 * * *$ & $0.285 * * *$ & $0.312 * * *$ & $0.293 * * *$ & & $-0.131 * *$ & $-0.120 * *$ & -0.053 & -0.079 & \\
\hline & $(6.322)$ & (6.243) & $(6.895)$ & $(6.430)$ & & $(-2.835)$ & $(-2.739)$ & $(-1.037)$ & $(-1.669)$ & \\
\hline \multirow[t]{2}{*}{ Supervisor support=1 } & $0.435^{* * *}$ & $0.441 * * *$ & $0.396 * * *$ & $0.445^{* * *}$ & $0.487 * * *$ & $-0.246 * *$ & $-0.276 * *$ & $-0.324 * * *$ & $-0.259 * *$ & $-0.206^{*}$ \\
\hline & $(4.952)$ & $(5.002)$ & $(4.396)$ & $(5.102)$ & $(5.337)$ & $(-3.055)$ & $(-3.269)$ & $(-3.582)$ & $(-2.961)$ & $(-2.446)$ \\
\hline \multirow[t]{2}{*}{ Age } & 0.008 & 0.018 & 0.019 & 0.017 & 0.025 & $0.064 *$ & 0.040 & 0.026 & 0.040 & 0.040 \\
\hline & $(0.305)$ & $(0.547)$ & $(0.601)$ & $(0.533)$ & $(0.791)$ & $(2.241)$ & (1.157) & $(0.718)$ & $(1.113)$ & (1.175) \\
\hline \multirow[t]{2}{*}{ Age squared } & -0.000 & -0.000 & -0.000 & -0.000 & -0.000 & $-0.001 *$ & -0.000 & -0.000 & -0.001 & -0.000 \\
\hline & $(-0.028)$ & $(-0.296)$ & $(-0.310)$ & $(-0.294)$ & $(-0.595)$ & $(-2.215)$ & $(-1.286)$ & $(-0.897)$ & $(-1.307)$ & $(-1.350)$ \\
\hline \multirow[t]{2}{*}{ Female } & $0.267^{* *}$ & $0.274 * *$ & $0.231^{*}$ & $0.266^{* *}$ & 0.185 & $0.322 * * *$ & $0.328 * * *$ & 0.194 & $0.267^{* *}$ & $0.275^{* *}$ \\
\hline & $(2.781)$ & $(2.871)$ & $(2.432)$ & $(2.775)$ & $(1.849)$ & (3.616) & $(3.500)$ & $(1.936)$ & $(2.813)$ & $(2.871)$ \\
\hline \multirow[t]{2}{*}{ Upper secondary } & -0.038 & -0.050 & 0.002 & -0.055 & -0.083 & 0.118 & 0.109 & 0.195 & 0.100 & 0.077 \\
\hline & $(-0.277)$ & $(-0.373)$ & $(0.014)$ & $(-0.411)$ & $(-0.572)$ & $(0.924)$ & $(0.818)$ & $(1.336)$ & $(0.762)$ & $(0.586)$ \\
\hline \multirow[t]{2}{*}{ Short-cycle tertiary } & -0.102 & -0.122 & -0.083 & -0.128 & -0.146 & 0.013 & 0.002 & 0.117 & -0.006 & -0.031 \\
\hline & $(-0.626)$ & $(-0.763)$ & $(-0.493)$ & $(-0.810)$ & $(-0.850)$ & $(0.079)$ & $(0.010)$ & $(0.661)$ & $(-0.037)$ & $(-0.185)$ \\
\hline \multirow[t]{2}{*}{ Bachelor's or equivalent } & -0.334 & -0.341 & -0.313 & -0.347 & $-0.373 *$ & 0.249 & 0.194 & 0.318 & 0.182 & 0.182 \\
\hline & $(-1.866)$ & $(-1.886)$ & $(-1.675)$ & $(-1.937)$ & $(-2.041)$ & $(1.464)$ & $(1.050)$ & $(1.603)$ & $(0.972)$ & $(1.000)$ \\
\hline
\end{tabular}




\begin{tabular}{|c|c|c|c|c|c|c|c|c|c|c|}
\hline Master's or equivalent & $\begin{array}{l}-0.546^{*} \\
(-2.554)\end{array}$ & $\begin{array}{l}-0.568^{* *} \\
(-2.648)\end{array}$ & $\begin{array}{l}-0.590 * * \\
(-2.706)\end{array}$ & $\begin{array}{l}-0.582^{* *} \\
(-2.723)\end{array}$ & $\begin{array}{l}-0.610^{* *} \\
(-2.789)\end{array}$ & $\begin{array}{l}0.192 \\
(1.035)\end{array}$ & $\begin{array}{l}0.173 \\
(0.894)\end{array}$ & $\begin{array}{l}0.272 \\
(1.267)\end{array}$ & $\begin{array}{l}0.123 \\
(0.643)\end{array}$ & $\begin{array}{l}0.142 \\
(0.742)\end{array}$ \\
\hline Doctoral or equivalent & $\begin{array}{l}0.194 \\
(0.391)\end{array}$ & $\begin{array}{l}0.200 \\
(0.404)\end{array}$ & $\begin{array}{l}0.244 \\
(0.504)\end{array}$ & $\begin{array}{l}0.155 \\
(0.326)\end{array}$ & $\begin{array}{l}0.252 \\
(0.430)\end{array}$ & $\begin{array}{l}-0.186 \\
(-0.452)\end{array}$ & $\begin{array}{l}-0.005 \\
(-0.015)\end{array}$ & $\begin{array}{l}0.120 \\
(0.397)\end{array}$ & $\begin{array}{l}-0.187 \\
(-0.488)\end{array}$ & $\begin{array}{l}-0.151 \\
(-0.434)\end{array}$ \\
\hline Tenure & $\begin{array}{l}-0.016 \\
(-0.961)\end{array}$ & $\begin{array}{l}-0.012 \\
(-0.686)\end{array}$ & $\begin{array}{l}-0.014 \\
(-0.786)\end{array}$ & $\begin{array}{l}-0.012 \\
(-0.729)\end{array}$ & $\begin{array}{l}-0.006 \\
(-0.352)\end{array}$ & $\begin{array}{l}-0.005 \\
(-0.359)\end{array}$ & $\begin{array}{l}-0.006 \\
(-0.350)\end{array}$ & $\begin{array}{l}0.002 \\
(0.093)\end{array}$ & $\begin{array}{l}-0.009 \\
(-0.576)\end{array}$ & $\begin{array}{l}-0.002 \\
(-0.095)\end{array}$ \\
\hline Tenure squared & $\begin{array}{l}0.000 \\
(0.715)\end{array}$ & $\begin{array}{l}0.000 \\
(0.517)\end{array}$ & $\begin{array}{l}0.000 \\
(0.666)\end{array}$ & $\begin{array}{l}0.000 \\
(0.583)\end{array}$ & $\begin{array}{l}0.000 \\
(0.140)\end{array}$ & $\begin{array}{l}0.000 \\
(0.566)\end{array}$ & $\begin{array}{l}0.000 \\
(0.290)\end{array}$ & $\begin{array}{l}-0.000 \\
(-0.108)\end{array}$ & $\begin{array}{l}0.000 \\
(0.570)\end{array}$ & $\begin{array}{l}0.000 \\
(0.260)\end{array}$ \\
\hline Log annual earnings & $\begin{array}{l}0.258^{*} \\
(1.970)\end{array}$ & $\begin{array}{l}0.331^{*} \\
(1.987)\end{array}$ & $\begin{array}{l}0.306 \\
(1.843)\end{array}$ & $\begin{array}{l}0.323^{*} \\
(1.965)\end{array}$ & $\begin{array}{l}0.549 * * * \\
(3.316)\end{array}$ & $\begin{array}{l}-0.317^{*} \\
(-2.425)\end{array}$ & $\begin{array}{l}-0.275 \\
(-1.453)\end{array}$ & $\begin{array}{l}-0.105 \\
(-0.505)\end{array}$ & $\begin{array}{l}-0.280 \\
(-1.461)\end{array}$ & $\begin{array}{l}-0.190 \\
(-1.060)\end{array}$ \\
\hline Log average income in the past ten years & & $\begin{array}{l}-0.059 \\
(-0.545)\end{array}$ & $\begin{array}{l}-0.124 \\
(-1.101)\end{array}$ & $\begin{array}{l}-0.055 \\
(-0.516)\end{array}$ & $\begin{array}{l}-0.108 \\
(-1.003)\end{array}$ & & $\begin{array}{l}0.142 \\
(0.958)\end{array}$ & $\begin{array}{l}0.064 \\
(0.409)\end{array}$ & $\begin{array}{l}0.154 \\
(1.006)\end{array}$ & $\begin{array}{l}0.068 \\
(0.481)\end{array}$ \\
\hline Unemployment during the past ten years & & $\begin{array}{l}0.041 \\
(0.968)\end{array}$ & $\begin{array}{l}0.033 \\
(0.766)\end{array}$ & $\begin{array}{l}0.043 \\
(1.008)\end{array}$ & $\begin{array}{l}0.036 \\
(0.830)\end{array}$ & & $\begin{array}{l}0.020 \\
(0.424)\end{array}$ & $\begin{array}{l}0.028 \\
(0.542)\end{array}$ & $\begin{array}{l}0.027 \\
(0.555)\end{array}$ & $\begin{array}{l}0.029 \\
(0.616)\end{array}$ \\
\hline Wage growth during the past ten years & & $\begin{array}{l}0.049 \\
(0.344)\end{array}$ & $\begin{array}{l}0.087 \\
(0.641)\end{array}$ & $\begin{array}{l}0.031 \\
(0.222) \\
\end{array}$ & $\begin{array}{l}0.047 \\
(0.344) \\
\end{array}$ & & $\begin{array}{l}-0.096 \\
(-0.560)\end{array}$ & $\begin{array}{l}-0.180 \\
(-0.996) \\
\end{array}$ & $\begin{array}{l}-0.164 \\
(-0.933) \\
\end{array}$ & $\begin{array}{l}-0.159 \\
(-0.950) \\
\end{array}$ \\
\hline Adjusted R-squared & 0.289 & 0.292 & 0.295 & 0.292 & 0.246 & 0.240 & 0.195 & 0.138 & 0.180 & 0.205 \\
\hline Observations & 1563 & 1563 & 1515 & 1563 & 1563 & 1563 & 1563 & 1515 & 1563 & 1563 \\
\hline
\end{tabular}

Notes: ${ }^{*}<<0.05 ;{ }^{* *} p<0.01 ;{ }^{* * *} p<0.001$. Variables included in the regressions but not reported in the table include industry (14 categories) and occupation (38 categories). "Job demands $0 / 1$ based on the scale" equals unity if the scale has a value that exceed the 75th percentile and zero otherwise. "Job demands $0 / 1$ " equals unity if the sum of Q25a, Q25b, Q25c, Q25d is less than 9 and zero otherwise. "Job demands based on Q16 Q18 and Q41c" is a scale and Q41c asks" Have you worked overtime in the last year so that employer initiated the overtime and it is not compensated for ( $\mathrm{Y} / \mathrm{N})$ ". 
Table A7: Job control, Job demands and supervisor support (Table 2) w/o log annual earnings as a control variable

\begin{tabular}{|c|c|c|c|c|c|c|c|c|c|c|}
\hline & (1) & (2) & (3) & (4) & (5) & (6) & (7) & (8) & (9) & (10) \\
\hline & Wellbein & Wellbein & Wellbein & Wellbein & Wellbein & & & & & \\
\hline & g & g & g & $\mathrm{g}$ & g & Stress & Stress & Stress & Stress & Stress \\
\hline \multirow[t]{3}{*}{ Job control scale } & $0.344 * * *$ & & & $0.296 * * *$ & $0.297 * * *$ & $-0.118^{*}$ & & & $-0.138 * *$ & $-0.140 * *$ \\
\hline & (8.193) & & & (6.467) & $(6.496)$ & $(-2.419)$ & & & $(-3.002)$ & $(-3.114)$ \\
\hline & & & & & & & $0.384 * *$ & & $0.395 * *$ & $0.404 * *$ \\
\hline \multirow[t]{3}{*}{ Job demands scale } & & 0.074 & & 0.048 & 0.045 & & & & $*$ & $*$ \\
\hline & & $(1.456)$ & & $(1.050)$ & (0.991) & & $(8.714)$ & & (9.481) & (9.784) \\
\hline & & & & & & & & - & & \\
\hline \multirow[t]{2}{*}{ Supervisor support=1 } & & & $0.535^{* * *}$ & $0.426 * * *$ & $0.429 * * *$ & & & $0.323 * * *$ & $-0.235 * *$ & $-0.235^{* *}$ \\
\hline & & & (5.975) & $(4.852)$ & $(4.890)$ & & & $(-3.750)$ & $(-2.906)$ & $(-2.942)$ \\
\hline \multirow[t]{3}{*}{ Age } & 0.013 & 0.011 & 0.027 & 0.020 & 0.025 & $0.076 * *$ & 0.054 & $0.068^{*}$ & 0.049 & 0.027 \\
\hline & (0.499) & $(0.413)$ & $(1.014)$ & $(0.770)$ & $(0.773)$ & $(2.774)$ & (1.935) & $(2.486)$ & $(1.822)$ & $(0.813)$ \\
\hline & & & & & & - & & & & \\
\hline \multirow[t]{3}{*}{ Age squared } & -0.000 & -0.000 & -0.000 & -0.000 & -0.000 & $0.001 * *$ & -0.001 & $-0.001^{*}$ & -0.001 & -0.000 \\
\hline & $(-0.113)$ & $(-0.117)$ & $(-0.748)$ & $(-0.425)$ & $(-0.502)$ & $(-2.835)$ & $(-1.929)$ & $(-2.490)$ & $(-1.831)$ & $(-0.943)$ \\
\hline & & & & & & & $0.400 * *$ & & $0.378 * *$ & $0.370 * *$ \\
\hline \multirow[t]{2}{*}{ Female } & $0.190 *$ & 0.177 & 0.159 & $0.222 *$ & $0.237^{*}$ & $0.192 *$ & $*$ & $0.198 *$ & $*$ & $*$ \\
\hline & (2.033) & $(1.677)$ & $(1.586)$ & (2.319) & $(2.443)$ & $(2.078)$ & $(4.768)$ & $(2.137)$ & $(4.467)$ & (4.148) \\
\hline \multirow[t]{2}{*}{ Upper secondary } & -0.040 & -0.188 & -0.150 & -0.039 & -0.037 & 0.177 & 0.191 & 0.207 & 0.120 & 0.106 \\
\hline & $(-0.283)$ & $(-1.206)$ & $(-0.985)$ & $(-0.289)$ & $(-0.272)$ & $(1.278)$ & (1.597) & $(1.516)$ & $(0.928)$ & $(0.839)$ \\
\hline \multirow[t]{2}{*}{ Short-cycle tertiary } & -0.094 & -0.256 & -0.216 & -0.100 & -0.100 & 0.098 & 0.086 & 0.132 & 0.011 & -0.016 \\
\hline & $(-0.538)$ & $(-1.336)$ & $(-1.203)$ & $(-0.613)$ & $(-0.616)$ & $(0.541)$ & $(0.543)$ & $(0.738)$ & $(0.069)$ & $(-0.099)$ \\
\hline \multirow[t]{2}{*}{ Bachelor's or equivalent } & -0.278 & -0.372 & -0.354 & -0.290 & -0.280 & 0.258 & 0.233 & 0.282 & 0.195 & 0.160 \\
\hline & $(-1.464)$ & $(-1.890)$ & $(-1.934)$ & $(-1.652)$ & $(-1.583)$ & (1.361) & $(1.402)$ & $(1.518)$ & (1.180) & $(0.963)$ \\
\hline \multirow[t]{2}{*}{ Master's or equivalent } & $-0.466^{*}$ & $-0.557^{*}$ & $-0.538^{*}$ & $-0.482 *$ & $-0.492 *$ & 0.193 & 0.148 & 0.217 & 0.113 & 0.104 \\
\hline & $(-2.091)$ & $(-2.196)$ & $(-2.361)$ & $(-2.307)$ & $(-2.360)$ & $(0.944)$ & (0.839) & (1.064) & $(0.638)$ & $(0.593)$ \\
\hline \multirow[t]{2}{*}{ Doctoral or equivalent } & 0.307 & 0.184 & 0.201 & 0.234 & 0.236 & 0.037 & -0.215 & 0.083 & -0.236 & -0.252 \\
\hline & (0.729) & $(0.471)$ & $(0.380)$ & $(0.484)$ & $(0.482)$ & (0.139) & $(-0.624)$ & $(0.284)$ & $(-0.593)$ & $(-0.642)$ \\
\hline
\end{tabular}




\begin{tabular}{|c|c|c|c|c|c|c|c|c|c|c|}
\hline Tenure & $\begin{array}{l}-0.018 \\
(-1.120)\end{array}$ & $\begin{array}{l}-0.008 \\
(-0.422)\end{array}$ & $\begin{array}{l}-0.002 \\
(-0.106)\end{array}$ & $\begin{array}{l}-0.013 \\
(-0.810)\end{array}$ & $\begin{array}{l}-0.012 \\
(-0.729)\end{array}$ & $\begin{array}{l}-0.003 \\
(-0.162)\end{array}$ & $\begin{array}{l}-0.011 \\
(-0.684)\end{array}$ & $\begin{array}{l}-0.010 \\
(-0.600)\end{array}$ & $\begin{array}{l}-0.008 \\
(-0.569)\end{array}$ & $\begin{array}{l}-0.006 \\
(-0.383)\end{array}$ \\
\hline Tenure squared & $\begin{array}{l}0.000 \\
(0.746)\end{array}$ & $\begin{array}{l}0.000 \\
(0.299)\end{array}$ & $\begin{array}{l}0.000 \\
(0.051)\end{array}$ & $\begin{array}{l}0.000 \\
(0.606)\end{array}$ & $\begin{array}{l}0.000 \\
(0.567)\end{array}$ & $\begin{array}{l}0.000 \\
(0.093)\end{array}$ & $\begin{array}{l}0.000 \\
(0.770)\end{array}$ & $\begin{array}{l}0.000 \\
(0.365)\end{array}$ & $\begin{array}{l}0.000 \\
(0.699)\end{array}$ & $\begin{array}{l}0.000 \\
(0.601)\end{array}$ \\
\hline Log average income in the past ten years & & & & & $\begin{array}{l}0.068 \\
(0.774)\end{array}$ & & & & & $\begin{array}{l}-0.042 \\
(-0.400)\end{array}$ \\
\hline Unemployment during the past ten years & & & & & $\begin{array}{l}0.028 \\
(0.705)\end{array}$ & & & & & $\begin{array}{l}0.049 \\
(1.079)\end{array}$ \\
\hline Wage growth during the past ten years & & & & & $\begin{array}{l}0.121 \\
(0.871) \\
\end{array}$ & & & & & $\begin{array}{l}-0.242 \\
(-1.565) \\
\end{array}$ \\
\hline Adjusted R-squared & 0.246 & 0.146 & 0.208 & 0.285 & 0.285 & 0.095 & 0.198 & 0.108 & 0.233 & 0.236 \\
\hline Observations & 1563 & 1563 & 1563 & 1563 & 1563 & 1563 & 1563 & 1563 & 1563 & 1563 \\
\hline
\end{tabular}

Notes: ${ }^{*} \mathrm{p}<0.05 ; * * \mathrm{p}<0.01 ; * * * \mathrm{p}<0.001$. Variables included in the regressions but not reported in the table include industry (14 categories) and occupation (38 categories). 